IZA DP No. 8132

Culture, Religiosity and Female Labor Supply

Duygu Guner

Gokce Uysal

April 2014 


\title{
Culture, Religiosity and Female Labor Supply
}

\author{
Duygu Guner \\ Katholieke Universiteit Leuven \\ Gokce Uysal \\ Bahcesehir University, Betam \\ and IZA
}
Discussion Paper No. 8132
April 2014

IZA
P.O. Box 7240
53072 Bonn
Germany

Phone: +49-228-3894-0

Fax: +49-228-3894-180

E-mail: iza@iza.org

Any opinions expressed here are those of the author(s) and not those of IZA. Research published in this series may include views on policy, but the institute itself takes no institutional policy positions. The IZA research network is committed to the IZA Guiding Principles of Research Integrity.

The Institute for the Study of Labor (IZA) in Bonn is a local and virtual international research center and a place of communication between science, politics and business. IZA is an independent nonprofit organization supported by Deutsche Post Foundation. The center is associated with the University of Bonn and offers a stimulating research environment through its international network, workshops and conferences, data service, project support, research visits and doctoral program. IZA engages in (i) original and internationally competitive research in all fields of labor economics, (ii) development of policy concepts, and (iii) dissemination of research results and concepts to the interested public.

IZA Discussion Papers often represent preliminary work and are circulated to encourage discussion. Citation of such a paper should account for its provisional character. A revised version may be available directly from the author. 


\section{ABSTRACT \\ Culture, Religiosity and Female Labor Supply}

Does culture affect female labor supply? In this paper, we address this question using a recent approach to measuring the effects of culture on economic outcomes, i.e. the epidemiological approach. We focus on migrants, who come from different cultures, but who share a common economic and institutional set-up today. Controlling for various individual characteristics including parental human capital as well as for current economic and institutional setup, we find that female employment rates in 1970 in a female migrant's province of origin affects her labor supply behavior in 2008. We also show that it is the female employment rates and not male in the province of origin in 1970 that affects the current labor supply behavior. We also extend the epidemiological approach to analyze the effects of religion on female labor supply. More specifically, we use a proxy of parental religiosity, i.e. share of party votes in 1973 elections in Turkey to study female labor supply in 2008. Our findings indicate that female migrants from provinces that had larger (smaller) shares of the religious party votes in 1973 are less (more) likely to participate in the labor market in 2008. An extended model where both cultural and religiosity proxies are included shows that culture and religiosity have separately significant effects on female labor supply behavior.

JEL Classification: J16, J21, Z10

Keywords: culture, female labor force participation, gender

Corresponding author:

Gokce Uysal

Bahçeşehir University - Betam

Center for Economic and Social Research

Osmanpaşa Mektebi Sok.

No: 4-6 Beşiktaş

İstanbul 34353

Turkey

E-mail: gokce.uysal@bahcesehir.edu.tr

\footnotetext{
* The authors would like to thank Pierre-Andre Chiappori, Seyfettin Gursel and Frederic Vermeulen as well as the seminar participants at Bahcesehir University, Bilgi University, Central Bank of the Republic of Turkey, Centre for European Economic Research (ZEW), Izmir University of Economics, Katholieke Universiteit Leuven, Middle East Technical University and The Université libre de Bruxelles as well as conference participants at the EEA 2013 Annual Meeting, the EALE 2013 Annual Meeting and the Labor Market Network Meeting 2. All remaining errors are our own.
} 


\section{Introduction}

Does culture affect economic outcomes? This has been one of the questions that has opened up a new line of research in the neoclassical economics literature. Even though social scientists have long been discussing the importance of culture in decision-making, economists had kept their distance given that culture is difficult to dene and even more difficult to measure. A recent approach has focused on the following amongst many different denitions of culture: customary beliefs and values that ethnic, religious and social groups transmit fairly unchanged from generation to generation (Guiso et al., 2006). This definition, as well as others that highlight the importance of the intergenerational transmission of culture have paved the way for a new identication strategy of measuring the effects of culture on various economic outcomes. Exploiting this definition of culture, recent research on culture's effects on economic outcomes used the epidemiological approach developed by Fernández (2008). In this approach, to quantify the effects of culture, researchers control for various individual characteristics as well as the current economic and institutional set-up, and test whether behavior in the country of origin has an effect on the behavior of the immigrant today. In empirical analyses, researchers have mainly focused on rst- and/or second-generations immigrants, who come from different parts of the World, but who share the same economic and institutional environment today in countries like the US, Canada and Australia.

Female labor supply is one of the areas where this approach is used to disentangle the effects of culture from those of markets. In doing so, we try to explain the variation in female LFPR across different immigrant groups residing in the same host country by using the variation in female LFPR in countries of origin, all the while controlling for various characteristics. This enables the separation of the effects of economic and institutional factors from cultural factors. Antecol (2000), Fernández and Fogli (2005a), Blau et al. (2008) and others consistently find that female LFPR in the country of origin affects LFPR in the host country for first- and second-generation women (see among others).

In this paper, we try to answer the same question and use a similar methodology, but we are in a different setting, Turkey, where there is very little international migration, but strong internal migration. Our contribution to the literature is three-fold. First, we apply the epidemiological approach to a within-country setting to study the female labor supply where internal migration influxes are strong and regional cultural differences exist. Second, we extend the epidemiological approach to get an unbiased estimate of the effects of religion on the female labor supply. Third, we contribute to the literature on the female labor supply in Turkey by quantifying the effects of culture.

There are a few reasons why Turkey provides a perfect setting for understanding the effects of culture on the female labor supply: (i) female labor force participation rates are low and structural factors cannot sufficiently explain the difference between Turkey and other similar countries (ii) regional differences are acute and persistent and (iii) there has been significant internal migration in the past couple of decades.

The labor market in Turkey is characterized by very low female labor force participation rates. At 30.2 percent, Turkey has the lowest female LFPR among the OECD countries in 2010. The urban female LFPR is even lower due to the high share of family farms in agriculture where women are working as unpaid family workers. In urban areas, female LFPR has been hovering around 20 percent in the past couple of decades and has slowly increased to 23.7 percent following a steady increase in education levels. However, we would like to point out that educational differences can only explain one third of the difference between Turkey and 
Table 1: Female LFPR in urban areas, 2008

\begin{tabular}{|c|c|c|}
\hline NUTS 2 & Classification (Cities in that region) & LFPR in \% \\
\hline 1 & İstanbul (Istanbul) & 22.1 \\
\hline 2 & Tekirdag (Edirne-Tekirdă̆-Kırklareli) & 31.7 \\
\hline 3 & Balıkesir (Balıkesir-Çanakkale) & 20.0 \\
\hline 4 & İzmir $\left(\dot{I}_{z m i r}\right)$ & 24.1 \\
\hline 5 & Aydın (Denizli-Aydın-Muğla) & 29.9 \\
\hline 6 & Manisa (Manisa-Afyonkarahisar-Kütahya-Uşak) & 15.7 \\
\hline 7 & Bursa (Bursa-Eskisehir-Bilecik) & 24.1 \\
\hline 8 & Kocaeli (Kocaeli-Sakarya-Düzce-Bolu-Yalova) & 21.1 \\
\hline 9 & Ankara (Ankara) & 23.2 \\
\hline 10 & Konya (Konya-Karaman) & 24.5 \\
\hline 11 & Antalya (Antalya-Isparta-Burdur) & 30.4 \\
\hline 12 & Adana (Adana-Mersin) & 21.5 \\
\hline 13 & Hatay (Hatay-Kahramanmaraş-Osmaniye) & 17.5 \\
\hline 14 & Kırıkkale (Nevsehir-Aksaray-Niğde-Kırıkkale-Kırşehir) & 13.2 \\
\hline 15 & Kayseri (Kayseri-Sivas-Yozgat) & 8.7 \\
\hline 16 & Zonguldak (Zonguldak-Karabük-Bartın) & 19.9 \\
\hline 17 & Kastamonu (Kastamonu-Çankırı-Sinop) & 19.7 \\
\hline 18 & Samsun (Samsun-Tokat-Çorum-Amasya) & 22.4 \\
\hline 19 & Trabzon (Trabzon-Ordu-Giresun-Rize-Artvin-Gümüşhane) & 36.2 \\
\hline 20 & Erzurum (Erzurum-Erzincan-Bayburt) & 17.3 \\
\hline 21 & A $\breve{g r} 1$ (Kars-A $\breve{g r i-I g ̆ d \imath r-A r d a h a n)}$ & 11.3 \\
\hline 22 & Malatya (Malatya-Elazı̆̆-Bingöl-Tunceli) & 13.0 \\
\hline 23 & Van (Van-Mus-Bitlis-Hakkari) & 8.0 \\
\hline 24 & Gaziantep (Gaziantep-Adıyaman-Kilis) & 9.0 \\
\hline 25 & Şanlıurfa (Diyarbakır-Şanlıurfa) & 5.4 \\
\hline 26 & Mardin (Siirt-Mardin-Batman-Şırnak) & 4.4 \\
\hline
\end{tabular}

similar countries in Southern Europe, such as Greece and Italy (Gürsel et al., 2011).

Even though urban female LFPR has been roughly constant over time, there are severe differences across regions in Turkey. Table 1 provides female LFPR in urban areas by regions. ${ }^{1}$ The lowest rate is in Southeast Anatolia, in Mardin (4.4 percent) whereas the highest rate is in the East Black Sea, in Trabzon (36.2 percent). These differences also exist in certain cultural traits. See Appendix A for graphical representations of regional differences in attitudes towards women's work and attitudes towards husband's help in household chores.

Furthermore, these regional differences in female LFPR are persistent. Figure 1 provides the non-agricultural female employment rate by province in 1970. Darker shades represent provinces with lower female employment rates in 1970. We exploit this inter-provincial variation in our analysis.

Unlike the US or Canada, Turkey does not receive large influxes of international immigrants. However, migration within Turkey has been exceptionally strong in the past three decades (Kocaman, 2008). Data in Table 1 shows that from 1975 to 1980, 3.6 million out of 38.4

\footnotetext{
${ }^{1}$ Provinces in NUTS2 regions are provided in parantheses.
} 
Figure 1: Female non-agricultural employment rates by province, 1970

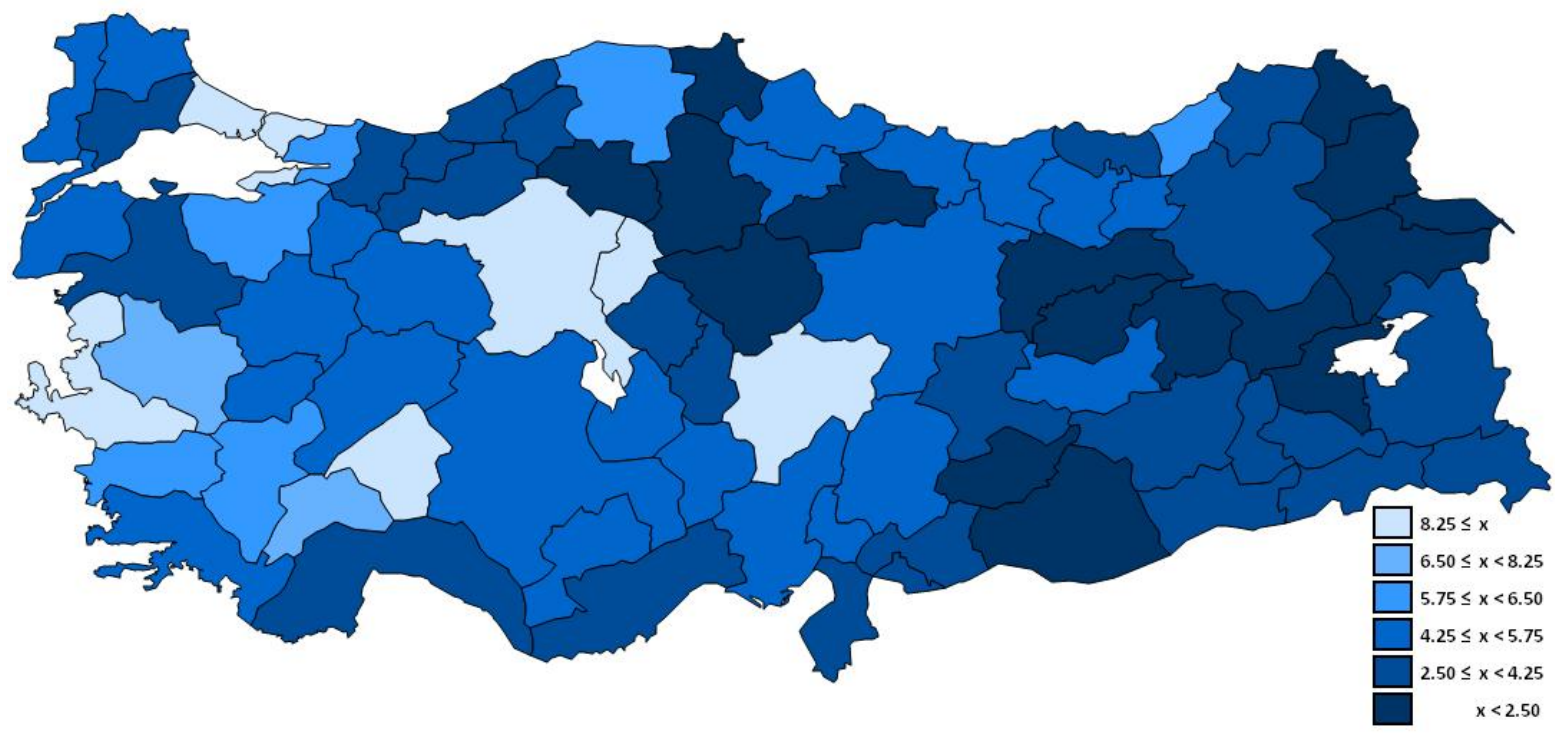

million $(9.3 \%)$ of people migrated within Turkey. 2.7 million people $(7 \%)$ migrated from one province to another. From 1980 to $1985,8.7 \%$ of the population migrated and $6.5 \%$ moved from one province to another. Internal migration remained strong in the second half of the 80 's and in the 90's as well.

Table 2: Internal Migration

\begin{tabular}{lrrrr} 
Period & $1975-1980$ & $1980-1985$ & $1985-1990$ & $1990-2000$ \\
\hline Population & $38,395,730$ & $44,078,033$ & $49,986,117$ & $60,752,995$ \\
Internal Migration & $3,584,421$ & $3,819,910$ & $5,402,690$ & $6,692,263$ \\
& $9.3 \%$ & $8.7 \%$ & $10.8 \%$ & $11.0 \%$ \\
Inter-Provincial Migration & $2,700,977$ & $2,885,873$ & $4,065,173$ & $4,788,193$ \\
& $7.0 \%$ & $6.5 \%$ & $8.1 \%$ & $7.9 \%$ \\
\hline
\end{tabular}

Source: Kocaman (2008)

To summarize, we use a variant of the epidemiological approach to study the effects of culture on the female labor supply in Turkey. Controlling for various individual characteristics as well as variables representing the current economic and institutional setting, we find that female employment rates in the province of origin around the time the migrants were born have an effect on female migrants' labor supply behavior. We find that one standard deviation increase in employment rates in 1970 in the province of origin increases the probability of female labor force participation by 3 percentage points. This effect may be smaller than the effect of a woman's own education level or that of her mother's, but it is still sizable. Our results also show that it is the female and not the male employment rates in 1970 that matter for the female labor supply of migrants.

We also use an arguable ingredient of culture in the last part of our analysis, religiosity. Another recent strand of the literature has focused on the effects of religion on the female labor supply. We use a measure of religiosity in province of origin as a proxy and find that a higher 
rate of religiosity in the province of origin affects the female labor supply negatively.

The remainder of this paper is organized as follows. Section 2 provides a brief discussion of the literature. The empirical strategy is presented in Section 3 and Section 4 describes the data sets used in the analysis. Section 5 discusses the estimation results. Section 6 concludes.

\section{Related Literature}

Quantifying the effects of culture on economic outcomes has become one of the recent interesting questions in the economics literature. Researchers are trying to determine whether differences in culture play a significant role in explaining differences in economic outcomes. Various outcomes have been scrutinized, such as savings, female labor supply and fertility, shirking behavior, economic development, labor market institutions, etc. In this paper, we focus on a strand of this literature on cultural economics that uses the epidemiological approach. The epidemiological approach is based on the behavior of first- or second- generation immigrants in countries that receive high international migration. Using the intergenerational transmission aspect of culture, where culture is defined as customary beliefs and values that ethnic, religious and social groups transmit fairly unchanged from generation to generation (Guiso et al. (2006)), this approach enables the isolation of the effects of culture from that of markets and institutions, which are common to immigrants in country of residence. Osili and Paulson (2004), Fernández and Fogli (2005b), Fernández and Fogli (2005a), Giuliano (2006) and Guiso et al. (2006) are some examples that use this methodology.

Given that our outcome of interest is the female labor supply, let us concentrate on research in this area. One of the first examples that studies the effects of culture on individual economic behavior is Levine (1993). Using the General Society Survey (US), the author shows that female attitudes concerning a woman's role is an important determinant of female labor force participation. Vella (1994) uses an Australian data set and finds that female attitudes toward working women have a dramatic effect on education, labor market attachment and returns to education of these women. Using cross-country data, Antecol (2000) shows that over half of the total variation in female LFPR of first-generation immigrant women can be explained by the female LFPR in country of origin. She concludes that culture, a permanent and portable factor, affects economic outcomes.

Fernández et al. (2002) study the effects of the husbands' attitude towards working women on married women's labor supply decisions. They argue that working mothers transform their sons' moral, religious and cultural beliefs regarding women's role and examine the relation between the labor supply decisions of the mothers of husbands and that of wives. Their analysis provides evidence that the probability of a man's wife working is positively and significantly correlated with his mother's labor market attachment.

A more recent paper of Fernández and Fogli (2005a) investigates the effects of culture on the labor supply and fertility behavior of second generation American women. The authors use past values of female labor force participation and total fertility rates in country of origin as instruments for culture. Their analysis suggests that culture can explain a significant part of labor supply and fertility behavior. They also test whether husbands' culture plays a significant role on the work and fertility decisions of married women and conclude that spouse's culture is an important determinant as well.

Blau et al. (2008) extend this analysis by investigating the effects of culture on fertility, labor force participation and education. They find that second generation immigrant women's outcomes are significantly positively affected by the first generation's outcomes. They con- 
clude that the estimated relationship is not due to unmeasured factors but rather is related to parental gender roles given that women's labor market participation has stronger effects on second generation females than on males. Finally, the authors find considerable intergenerational assimilation toward native levels of schooling and labor supply.

Almost all of epidemiological approach literature focuses on international migration to isolate the effects of culture from that of markets. However, this approach proves to also be useful also in countries where internal migration is strong and regional disparities are large and persistent. Ichino and Maggi (1999) use variation across Northern and Southern Italy to study the effects of culture in shirking behavior of employees in a large Italian bank. The authors find a significant relationship between region of birth and level of shirking even after controlling for individual characteristics.

We contribute to the existing literature by studying the effects of culture on female labor supply decisions by using regional variation across Turkey where influxes of internal migration were strong and regional differences are acute.

Our paper also contributes to the economics of religion literature. More specifically, ours is the first study to apply the epidemiological approach to study the effects of religiosity on female labor supply. The literature on religion and economics has studied the effects of religion on attitudes and economic outcomes such as growth, occupational choice, education and female labor supply. Guiso et al. (2003) study the effect of religion on economic attitudes using World Values Surveys. Their results indicate that religious people have a more conservative attitude towards women's work. They find that this effect is twice as strong for Muslims than for any other religion. Heineck (2004) shows that women with stronger religious beliefs are less likely to participate in the labor market in Germany. Using international surveys, Algan and Cahuc (2006) document that Catholics and Muslims are more likely to agree with the traditional gender division of work. However, none of the aforementioned papers discuss the endogenity of current religious practices and attitudes or the endogeneity of religion and female labor supply decisions. We use a proxy for religiosity to overcome this problem and establish causality. Still focusing on the migrants, we control for the share of party votes in 1973 elections in province of origin as a proxy for religiosity. The 1973 elections are important in the political history of Turkey as these are the first elections in which a party, National Salvation Party (MSP), had a clear Islamist agenda as pointed out by Sarıbay (1985) and Sarıbay (2004).

Lastly, even though a considerable amount of work has been done on the female labor supply in Turkey, a vast majority of them do not take into account the effects of culture. See Tansel (2001), Başlevent and İnsan Tunalı (2005), Dayığlu and Kırdar (2009) and Taymaz (2009) among others. Only İkkaracan (2012) mentions the potential effects of culture on female labor supply decisions, but does not include a measure of culture in her analysis. In a recent paper, Göksel (2013) analyzes the effects of current attitudes and social norms on the female labor supply, however, her results are affected by the endogeneity of current attitudes and labor supply behavior. Ours is the only work to study the cultural determinants of female labor supply in Turkey that addresses the endogeneity of cultural attitudes and religion to the female labor supply. 


\section{Empirical Strategy}

Our goal is to analyze the effects of cultural attitudes on the labor force participation decision of females in Turkey using the epidemiological approach. ${ }^{2}$ Cultural attitudes may shape labor force participation decisions of women by imposing a more traditional division of labor at home. ${ }^{3}$

The female labor force participation decision may be estimated using Equation 1 where $L F P_{i t}$ stands for the participation decision of woman $i$ in period $t, X_{i t}$ denotes a vector of characteristics of woman $i$ such as age, education, etc, and $W_{t}$ are regional dummies, all in period $t$. $Z_{i t}$ represents the cultural attitudes towards the work of woman $i$ in period $t$. The cultural attitude towards work, $Z_{i t}$ may be correlated with the error term $\epsilon_{i t}$. More importantly, labor force participation probably affects cultural attitudes towards work as well. Given the endogeneity concerns, we opt for a proxy for the current cultural attitudes $Z_{i t}$.

$$
L F P_{i t}=\beta_{0}+\beta_{1} X_{i t}+\beta_{2} Z_{i t}+\beta_{3} W_{t}+\epsilon_{i t}
$$

Our choice of proxy for current cultural attitudes is based on work by Bisin and Verdier (2001) and Bénabou and Tirole (2006), where authors posit that cultural attitudes are shaped by contemporaneous environments as well as inherited attitudes from earlier generations. In other words, preferences are formed through an adaptation and imitation process. There are two channels that affect preference formation, or cultural attitudes in our context, parents' preferences and environmental factors, i.e. the current cultural and social environment. Following this work, Tabellini (2007) and Algan and Cahuc (2010) form a model of culture where culture is a function of the culture of the previous generation and of the contemporaneous factors that may affect economic outcomes. Equation 2 is constructed in a similar manner: $X_{i t}$ represents the current economic characteristics, $Z_{i t-1}$ the cultural attitudes towards work of the previous generation and $W_{t}$ the current institutional setting.

$$
Z_{i t}=\alpha_{0}+\alpha_{1} X_{i t}+\alpha_{2} Z_{i t-1}+\alpha_{3} W_{t}+\gamma_{i t}
$$

Unfortunately, we do not have a direct measure of the previous generation's cultural attitudes toward female paid work. However, the previous generation's behavior probably summarizes this attitude. Following this thought, we use the female labor supply behavior of the previous generation, i.e. in $t-1$ as a proxy. More specifically, our proxy is the female non-agricultural employment rates in $1970\left(E R_{1970}\right)$ in province of origin for migrant women in Turkey who are observed in 2008. This proxy, $E R_{1970}$, has desirable properties as it is not correlated with the error term $\epsilon_{i t}$ in Equation 1. In other words, female non-agricultural employment rates in 1970 affect the labor force participation decision of women in 2008 only through the effects on cultural attitudes in 2008.

We start our analysis by controlling for age and our proxy for culture, i.e. female nonagricultural employment rates in 1970. Then we extend the analysis to include the standard control variables for female labor supply. Clearly, many factors other than culture may be transmitted from parents to their children, the most relevant one for the labor market being

\footnotetext{
${ }^{2}$ It would have been more informative to study the effects of culture on hours worked as well since hours worked provides a better measure of labor supply. Unfortunately, the data set we use does not provide any information on hours worked, but only on labor force participation.

${ }^{3} \mathrm{~A}$ more traditional division of labor dictates that men work in the labor market for pay whereas women focus on the household production.
} 
human capital. Our data set contains information on the literacy of parents of the ever-married women. We use this variable to control for parental human capital. ${ }^{4}$

To account for differing labor market conditions in the current place of residence, we also include regional dummies and provincial unemployment rates as well as the relative size of the service sector, which traditionally provides more employment opportunities for women.

\section{Data}

The data used comes from different sources. The main micro level data is provided by Turkey Demographic and Health Survey (TDHS) of 2008. TDHS collects nationally representative data on a wide range of topics including fertility, labor force participation, history of migration and education as well as other indicators of socioeconomic status. We use the Ever-MarriedWomen Module, which collects detailed data on women who were married at least once and who are between the ages of 15 and 49. This is the only module that contains information on migration and labor market status at the same time.

However, TDHS does not have any information on the labor force status of the mothers of the women in the sample, i.e. our proxy for culture. Hence we construct this proxy using Census data. The mean age of women in our sample is 34, which implies that the average year of birth of these women is 1974. Therefore we use data from the 1970 Census of Turkey to compute the non-agricultural employment rates by province since the Census does not provide information on job search, making it impossible to calculate labor force participation rates. Data on current labor market conditions are taken from the Household Labor Force Survey (HLFS) of 2008. HLFS is the largest data set available to researchers on the labor market in Turkey.

TDHS Women's Questionnaire provides a data set that contains 7,703 women, who have been married at least once and are between the ages 15 and 49. However, we limit our analysis to women living in urban areas. ${ }^{5}$ Note that our analysis is based on women who have migrated (1818 women). Women are migrants if their current province of residence is different than their province of birth. We also use province of main residence before the age of 12 to identify migrants. The results are qualitatively and quantitatively similar. ${ }^{6}$ We also exclude women who are not currently married (14 women in urban areas) and those who do not report the province of main residence before the age of 12 (79 women in urban areas). There are 1759 women who satisfy all of these conditions and they account for 32.5 percent of the sample who are married, currently residing in urban areas and who participated in the Ever-Married Women's Module (5408 women).

Table 3 provides the descriptive statistics for migrant (our sample) and non-migrant women (age 15 to 49, married and currently residing in urban areas from the Ever-Married Women's Module).

Migrant and non-migrant women are very similar. The mean age is 33.9 for migrant women and 33.6 for non-migrant women. One major difference is in education levels. Migrant women are more likely to be university graduates (11.8 percent vs. 5.6 percent). Migrant women are less likely to have children younger than 5 . They are also more likely to be in the richest

\footnotetext{
${ }^{4}$ Only 43.8 percent of mothers and 81 percent of fathers of these women were literate. We also tried primary education as a proxy for father's human capital, the results were similar.

${ }^{5}$ Given that women are working predominantly as unpaid family workers in agricultural areas, we exclude the rural population.

${ }^{6}$ Results are available upon request.
} 
quintile, but this may be due to higher education levels given marital sorting. The probability of having a literate parent is slightly higher for migrant women.

Nevertheless, the difference between regional distributions of migrant vs. non-migrant women is striking. Migrant women are more likely to reside in Istanbul, Aegean and East Marmara. These are the regions that have historically been receiving high influxes of internal migration. On the other hand, non-migrant women are more likely to reside in the Eastern part of Turkey, i.e. Northeast Anatolia, Central East Anatolia and Southeast Anatolia.

The last column provides statistics from the Household Labor Force Survey of $2008 .{ }^{7}$ Clearly, our sample is very similar to the HLFS, except for the regional distribution. The age distribution is almost the same. In terms of education, the migrant women are more likely to have graduated from tertiary education, however, given the small sample size, this difference may be tolerable. However, there are major discrepancies in the regional distribution. HLFS data indicates that more women reside in the western part of Turkey (Istanbul, Aegean, East Marmara, West Anatolia and the Mediterranean) than is implied by the TDHS. TDHS has more women who reside in the eastern part of Turkey (East Black Sea, Northeast Anatolia, Central East Anatolia and Southeast Anatolia). ${ }^{8}$

Table 4 presents our control for culture: female employment rates in non-agricultural sectors in 1970. Overall, only 4.62 percent of women older than 12 are working in non-agricultural sectors in 1970. This rate is as low as 1.25 in Adryaman and as high as 16.24 percent in Isparta.

To make sure that our results are not driven by migrants from provinces with higher female employment rates in 1970, we plot the number of observations and female employment rates by province in Figure 4. Data clearly shows that the observations are randomly distributed across provinces.

\section{$5 \quad$ Estimation Results}

We start our analysis by concentrating on culture and the female labor supply. We start out with a very basic model where we control only for age and culture. Then we extend our model to include standard, but possible endogenous determinants of the female labor force participation decision. Then, we apply the same method to establish a relation between religion and female labor supply. The marginal effects are provided at the end of this section.

\subsection{Culture and female labor supply}

Our dependent variable $L F P_{\text {Female }}$ is a dummy variable that equals to 1 for those who are employed in non-agricultural sectors and for those who are looking for a job and 0 otherwise. In this respect, this is a non-agricultural labor force participation measure. ${ }^{9}$

\footnotetext{
${ }^{7}$ Again, we restrict the HLFS data to married women between the ages of 15 and 49 currently residing in urban areas.

${ }^{8}$ TDHS is a household level data set representative data set at the NUTS1 level. However, it may not be representative of the ever-married women at this divide.

${ }^{9}$ Limiting the analysis to non-agricultural sectors is crucial for any research on the labor market in Turkey given that there is literally no unemployment in agriculture. In 2008, there are 21 million 194 thousand people who are employed and 5 million 16 thousand of them are employed in agriculture. However, there were only 64 thousand people who were unemployed in agriculture. This implies an agricultural unemployment rate of $1.3 \%$, which is much lower than the aggregate unemployment rate of $11.0 \%$. The situation is similar albeit more pronounced for women. $42.1 \%$ of working women are employed in agriculture (2 million 234 thousand out of 5 million 595 thousand) and there are only 16 thousand women unemployed in agriculture. Female unemployment rate in agriculture is negligible at $0.7 \%$ compared to aggregate female unemployment rate of $11.6 \%$. Moreover,
} 
Table 3: Descriptive Statistics

\begin{tabular}{|c|c|c|c|c|c|c|c|}
\hline & \multicolumn{2}{|c|}{ Migrants } & \multicolumn{2}{|c|}{ Non-migrants } & \multicolumn{2}{|c|}{ Total } & \multirow{2}{*}{$\begin{array}{c}\text { HLFS } \\
\text { share }\end{array}$} \\
\hline & level & share & level & share & level & share & \\
\hline Non-agricultural LFPR & 499 & $28.4 \%$ & 774 & $21.2 \%$ & 1,273 & $23.5 \%$ & $18.2 \%$ \\
\hline \multicolumn{8}{|l|}{ Age } \\
\hline Aged 15-19 & 46 & $2.6 \%$ & 110 & $3.0 \%$ & 156 & $2.9 \%$ & $2.1 \%$ \\
\hline Aged 20-24 & 186 & $10.6 \%$ & 491 & $13.5 \%$ & 677 & $12.5 \%$ & $10.2 \%$ \\
\hline Aged 25-29 & 378 & $21.5 \%$ & 668 & $18.3 \%$ & 1,046 & $19.3 \%$ & $19.4 \%$ \\
\hline Aged 30-34 & 334 & $19.0 \%$ & 719 & $19.7 \%$ & 1,053 & $19.5 \%$ & $19.5 \%$ \\
\hline Aged 35-39 & 320 & $18.2 \%$ & 656 & $18.0 \%$ & 976 & $18.0 \%$ & $18.1 \%$ \\
\hline Aged 40-44 & 255 & $14.5 \%$ & 553 & $15.2 \%$ & 808 & $14.9 \%$ & $16.4 \%$ \\
\hline Aged 45-49 & 240 & $13.6 \%$ & 452 & $12.4 \%$ & 692 & $12.8 \%$ & $14.2 \%$ \\
\hline Total & 1,759 & $100 \%$ & 3,649 & $100 \%$ & 5,408 & $100 \%$ & $100 \%$ \\
\hline \multicolumn{8}{|l|}{ Education } \\
\hline Non-graduates & 259 & $14.7 \%$ & 565 & $15.5 \%$ & 824 & $15.2 \%$ & $14.6 \%$ \\
\hline Primary school & 836 & $47.5 \%$ & 1,952 & $53.5 \%$ & 2,788 & $51.6 \%$ & $50.3 \%$ \\
\hline Secondary school & 170 & $9.7 \%$ & 344 & $9.4 \%$ & 514 & $9.5 \%$ & $10.0 \%$ \\
\hline High school & 287 & $16.3 \%$ & 584 & $16.0 \%$ & 871 & $16.1 \%$ & $16.9 \%$ \\
\hline University or more & 207 & $11.8 \%$ & 204 & $5.6 \%$ & 411 & $7.6 \%$ & $8.2 \%$ \\
\hline Total & 1,759 & $100 \%$ & 3,649 & $100 \%$ & 5,408 & $100 \%$ & $100 \%$ \\
\hline \multicolumn{8}{|l|}{ Children under 5} \\
\hline None & 952 & $54.1 \%$ & 1,893 & $51.9 \%$ & 2,845 & $52.6 \%$ & $64.7 \%$ \\
\hline One & 587 & $33.4 \%$ & 1,225 & $33.6 \%$ & 1,812 & $33.5 \%$ & $28.9 \%$ \\
\hline Two & 182 & $10.3 \%$ & 438 & $12.0 \%$ & 620 & $11.5 \%$ & $5.9 \%$ \\
\hline Three & 32 & $1.8 \%$ & 89 & $2.4 \%$ & 121 & $2.2 \%$ & $0.5 \%$ \\
\hline Four & 6 & $0.3 \%$ & 1 & $0.0 \%$ & 7 & $0.1 \%$ & $0.0 \%$ \\
\hline Five or more & 0 & $0.0 \%$ & 3 & & 3 & $0.1 \%$ & $0.0 \%$ \\
\hline Total & 1,759 & $100 \%$ & 3,649 & $100 \%$ & 5,408 & $100 \%$ & $100 \%$ \\
\hline \multicolumn{8}{|l|}{ Wealth index } \\
\hline Poorest & 123 & $7.0 \%$ & 403 & $11.0 \%$ & 526 & $9.7 \%$ & ** \\
\hline Poorer & 287 & $16.3 \%$ & 851 & $23.3 \%$ & 1,138 & $21.0 \%$ & ** \\
\hline Middle & 419 & $23.8 \%$ & 878 & $24.1 \%$ & 1,297 & $24.0 \%$ & ** \\
\hline Richer & 485 & $27.6 \%$ & 81 & $22.4 \%$ & 1,302 & $24.1 \%$ & ** \\
\hline Richest & 445 & $25.3 \%$ & 700 & $19.2 \%$ & 1,145 & $21.2 \%$ & ** \\
\hline Total & 1,759 & $100 \%$ & 3,649 & $100 \%$ & 5,408 & $100 \%$ & ** \\
\hline Mother literate & 771 & $43.8 \%$ & 1,480 & $40.6 \%$ & 2,251 & $41.6 \%$ & ** \\
\hline Father literate & 1,425 & $81.0 \%$ & 2,908 & $79.7 \%$ & 4,333 & $80.1 \%$ & ** \\
\hline \multicolumn{8}{|l|}{ Region } \\
\hline Istanbul & 307 & $17.5 \%$ & 148 & $4.1 \%$ & 455 & $8.4 \%$ & $25.6 \%$ \\
\hline West Marmara & 86 & $4.9 \%$ & 194 & $5.3 \%$ & 280 & $5.2 \%$ & $3.5 \%$ \\
\hline Aegean & 163 & $9.3 \%$ & 188 & $5.2 \%$ & 351 & $6.5 \%$ & $12.8 \%$ \\
\hline East Marmara & 224 & $12.7 \%$ & 206 & $5.6 \%$ & 430 & $8.0 \%$ & $11.0 \%$ \\
\hline West Anatolia & 127 & $7.2 \%$ & 283 & $7.8 \%$ & 410 & $7.6 \%$ & $11.7 \%$ \\
\hline Mediterranean & 212 & $12.1 \%$ & 466 & $12.8 \%$ & 678 & $12.5 \%$ & $12.0 \%$ \\
\hline Central Anatolia & 98 & $5.6 \%$ & 279 & $7.6 \%$ & 377 & $7.0 \%$ & $4.4 \%$ \\
\hline West Black Sea & 115 & $6.5 \%$ & 320 & $8.8 \%$ & 435 & $8.0 \%$ & $4.8 \%$ \\
\hline East Black Sea & 73 & $4.2 \%$ & 228 & $6.2 \%$ & 301 & $5.6 \%$ & $1.7 \%$ \\
\hline Northeast Anatolia & 67 & $3.8 \%$ & 369 & $10.1 \%$ & 436 & $8.1 \%$ & $1.7 \%$ \\
\hline Central East Anatolia & 93 & $5.3 \%$ & 325 & $8.9 \%$ & 418 & $7.7 \%$ & $3.0 \%$ \\
\hline Southeast Anatolia & 194 & $11.0 \%$ & 643 & $17.6 \%$ & 837 & $15.5 \%$ & $7.8 \%$ \\
\hline Total & 1,759 & $100 \%$ & 3,649 & $100 \%$ & 5,408 & $100 \%$ & $100 \%$ \\
\hline
\end{tabular}

Source:TDHS 2008, HLFS 2008 
Table 4: Female employment rates in non-agricultural sectors (percent, 1970)

\begin{tabular}{|c|c|c|c|c|c|}
\hline Code & City & $E R_{1970}$ & Code & City & $E R_{1970}$ \\
\hline 1 & Adana & 4.70 & 42 & Konya & 5.51 \\
\hline 2 & Adryaman & 1.25 & 43 & Kütahya & 4.63 \\
\hline 3 & Afyonkarahisar & 4.90 & 44 & Malatya & 3.40 \\
\hline 4 & A ̆̆r1 & 1.95 & 45 & Manisa & 7.70 \\
\hline 5 & Amasya & 4.33 & 46 & Maraş & 4.58 \\
\hline 6 & Ankara & 9.95 & 47 & Mardin & 4.20 \\
\hline 7 & Antalya & 3.36 & 48 & Muğla & 4.42 \\
\hline 8 & Artvin & 3.10 & 49 & Muş & 2.36 \\
\hline 9 & Aydın & 6.66 & 50 & Nevşehir & 2.96 \\
\hline 10 & Balikesir & 4.18 & 51 & Niğgde & 5.68 \\
\hline 11 & Bilecik & 4.36 & 52 & Ordu & 5.44 \\
\hline 12 & Bingöl & 2.08 & 53 & Rize & 6.14 \\
\hline 13 & Bitlis & 1.79 & 54 & Sakarya & 3.28 \\
\hline 14 & Bolu & 3.50 & 55 & Samsun & 4.58 \\
\hline 15 & Burdur & 8.05 & 56 & Siirt & 3.73 \\
\hline 16 & Bursa & 5.76 & 57 & Sinop & 2.28 \\
\hline 17 & Çanakkale & 4.55 & 58 & Sivas & 4.58 \\
\hline 18 & Çankırı & 1.88 & 59 & Tekirdağ & 3.27 \\
\hline 19 & Çorum & 2.30 & 60 & Tokat & 2.60 \\
\hline 20 & Denizli & 6.47 & 61 & Trabzon & 3.96 \\
\hline 21 & Diyarbakır & 3.14 & 62 & Tunceli & 2.56 \\
\hline 22 & Edirne & 5.28 & 63 & Şanlıurfa & 2.47 \\
\hline 23 & Elaziğ & 4.79 & 64 & Uşak & 4.89 \\
\hline 24 & Erzincan & 2.37 & 65 & Van & 3.83 \\
\hline 25 & Erzurum & 4.02 & 66 & Yozgat & 1.76 \\
\hline 26 & Eskişehir & 4.61 & 67 & Zonguldak & 2.87 \\
\hline 27 & Gaziantep & 4.01 & 68 & Aksaray & 5.68 \\
\hline 28 & Giresun & 5.05 & 69 & Bayburt & 4.38 \\
\hline 29 & Gümüshane & 4.38 & 70 & Karaman & 5.51 \\
\hline 30 & Hakkari & 4.04 & 71 & Kırıkkale & 9.95 \\
\hline 31 & Hatay & 3.45 & 72 & Batman & 4.20 \\
\hline 32 & Isparta & 16.24 & 73 & Şırnak & 3.73 \\
\hline 33 & İçel & 3.91 & 74 & Bartın & 2.87 \\
\hline 34 & İstanbul & 12.13 & 75 & Ardahan & 2.26 \\
\hline 35 & İzmir & 9.46 & 76 & Iğdır & 2.26 \\
\hline 36 & Kars & 2.26 & 77 & Yalova & 12.13 \\
\hline 37 & Kastamonu & 5.89 & 78 & Karabük & 2.87 \\
\hline 38 & Kayseri & 9.27 & 79 & Kilis & 4.01 \\
\hline 39 & Kırklareli & 4.49 & 80 & Osmaniye & 4.70 \\
\hline 40 & Kırşehir & 3.40 & 81 & Düzce & 3.50 \\
\hline 41 & Kocaeli & 5.91 & & & \\
\hline
\end{tabular}

Source: Population Census 1970 
Table 5: Estimation results- Birth place

\begin{tabular}{|c|c|c|c|c|c|c|c|}
\hline & (1) & $(2)$ & $(3)$ & $(4)$ & $(5)$ & $(6)$ & (7) \\
\hline$E R_{1970}$ & $\begin{array}{c}0.089^{* * *} \\
(0.015)\end{array}$ & $\begin{array}{c}0.050^{* * *} \\
(0.018)\end{array}$ & $\begin{array}{c}0.051^{* * *} \\
(0.018)\end{array}$ & $\begin{array}{c}0.048^{* * *} \\
(0.017)\end{array}$ & $\begin{array}{c}0.040^{* * *} \\
(0.017)\end{array}$ & $\begin{array}{c}0.043^{* *} \\
(0.020)\end{array}$ & \\
\hline Male $E R_{1970 c}$ & & & & & & $\begin{array}{l}0.000 \\
(0.003)\end{array}$ & \\
\hline$G A P_{1970 a}$ & & & & & & & $\begin{array}{c}0.014^{* *} \\
(0.007)\end{array}$ \\
\hline Current age & $\begin{array}{c}0.175^{* * *} \\
(0.048)\end{array}$ & $\begin{array}{c}0.163^{* * *} \\
(0.054)\end{array}$ & $\begin{array}{c}0.164^{* * *} \\
(0.054)\end{array}$ & $\begin{array}{c}0.166^{* * *} \\
(0.053)\end{array}$ & $\begin{array}{c}0.151^{* * *} \\
(0.056)\end{array}$ & $\begin{array}{c}0.151^{* * *} \\
(0.056)\end{array}$ & $\begin{array}{c}0.149^{* * *} \\
(0.056)\end{array}$ \\
\hline Age squared & $\begin{array}{c}-0.003^{* * *} \\
(0.001)\end{array}$ & $\begin{array}{c}-0.002^{* * *} \\
(0.001)\end{array}$ & $\begin{array}{c}-0.002^{* * *} \\
(0.001)\end{array}$ & $\begin{array}{c}-0.002^{* * *} \\
(0.001)\end{array}$ & $\begin{array}{c}-0.002^{* *} \\
(0.001)\end{array}$ & $\begin{array}{c}-0.002^{* *} \\
(0.001)\end{array}$ & $\begin{array}{c}-0.002^{* *} \\
(0.001)\end{array}$ \\
\hline Age at migration & $\begin{array}{c}-0.009^{*} \\
(0.005)\end{array}$ & $\begin{array}{l}-0.006 \\
(0.006)\end{array}$ & $\begin{array}{l}-0.006 \\
(0.006)\end{array}$ & $\begin{array}{l}-0.006 \\
(0.006)\end{array}$ & $\begin{array}{l}-0.005 \\
(0.006)\end{array}$ & $\begin{array}{l}-0.005 \\
(0.006)\end{array}$ & $\begin{array}{l}-0.005 \\
(0.006)\end{array}$ \\
\hline Schooling & & $\begin{array}{c}0.173^{* * *} \\
(0.062)\end{array}$ & $\begin{array}{c}0.166^{* * *} \\
(0.064)\end{array}$ & $\begin{array}{c}0.165^{* *} \\
(0.066)\end{array}$ & $\begin{array}{c}0.139^{* *} \\
(0.068)\end{array}$ & $\begin{array}{c}0.139^{* *} \\
(0.068)\end{array}$ & $\begin{array}{c}0.142^{* *} \\
(0.068)\end{array}$ \\
\hline Schooling squared & & $\begin{array}{c}-0.032^{* * *} \\
(0.011)\end{array}$ & $\begin{array}{c}-0.032^{* * *} \\
(0.011)\end{array}$ & $\begin{array}{c}-0.033^{* * *} \\
(0.011)\end{array}$ & $\begin{array}{c}-0.029^{* *} \\
(0.011)\end{array}$ & $\begin{array}{c}-0.029 * * \\
(0.011)\end{array}$ & $\begin{array}{c}-0.028^{* *} \\
(0.011)\end{array}$ \\
\hline Schooling cubed & & $\begin{array}{c}0.002^{* * *} \\
(0.001)\end{array}$ & $\begin{array}{c}0.002^{* * *} \\
(0.001)\end{array}$ & $\begin{array}{c}0.002^{* * * *} \\
(0.001)\end{array}$ & $\begin{array}{c}0.002^{* * *} \\
(0.001)\end{array}$ & $\begin{array}{c}0.002^{* * *} \\
(0.001)\end{array}$ & $\begin{array}{c}0.002^{* * *} \\
(0.001)\end{array}$ \\
\hline Number of children $\leq 5$ & & $\begin{array}{c}-0.197^{* * *} \\
(0.074)\end{array}$ & $\begin{array}{c}-0.192^{* *} \\
(0.076)\end{array}$ & $\begin{array}{c}-0.190^{* *} \\
(0.077)\end{array}$ & $\begin{array}{c}-0.173^{* *} \\
(0.078)\end{array}$ & $\begin{array}{c}-0.172^{* *} \\
(0.078)\end{array}$ & $\begin{array}{c}-0.183^{* *} \\
(0.078)\end{array}$ \\
\hline Wealth index & & & $\begin{array}{l}0.145^{*} \\
(0.075)\end{array}$ & $\begin{array}{l}0.127^{*} \\
(0.077)\end{array}$ & $\begin{array}{c}0.096 \\
(0.081)\end{array}$ & $\begin{array}{c}0.096 \\
(0.081)\end{array}$ & $\begin{array}{c}0.088 \\
(0.080)\end{array}$ \\
\hline Wealth index squared & & & $\begin{array}{c}-0.114^{* *} \\
(0.049)\end{array}$ & $\begin{array}{c}-0.113^{* *} \\
(0.051)\end{array}$ & $\begin{array}{c}-0.094^{*} \\
(0.054)\end{array}$ & $\begin{array}{c}-0.094^{*} \\
(0.054)\end{array}$ & $\begin{array}{l}-0.086 \\
(0.053)\end{array}$ \\
\hline Mother literate & & & & $\begin{array}{c}0.184^{* *} \\
(0.085)\end{array}$ & $\begin{array}{c}0.184^{* *} \\
(0.087)\end{array}$ & $\begin{array}{c}0.184^{* *} \\
(0.087)\end{array}$ & $\begin{array}{c}0.210^{* *} \\
(0.086)\end{array}$ \\
\hline Father literate & & & & $\begin{array}{l}-0.055 \\
(0.124)\end{array}$ & $\begin{array}{l}-0.119 \\
(0.111)\end{array}$ & $\begin{array}{l}-0.119 \\
(0.111)\end{array}$ & $\begin{array}{c}-0.117 \\
(0.110)\end{array}$ \\
\hline West Marmara & & & & & $\begin{array}{c}0.221 \\
(0.154)\end{array}$ & $\begin{array}{c}0.221 \\
(0.155)\end{array}$ & $\begin{array}{c}0.246 \\
(0.157)\end{array}$ \\
\hline Aegean & & & & & $\begin{array}{c}0.258^{* * *} \\
(0.087)\end{array}$ & $\begin{array}{c}0.259^{* * *} \\
(0.087)\end{array}$ & $\begin{array}{c}0.267^{* * *} \\
(0.084)\end{array}$ \\
\hline East Marmara & & & & & $\begin{array}{c}0.357^{* * *} \\
(0.112)\end{array}$ & $\begin{array}{c}0.356^{* * *} \\
(0.113)\end{array}$ & $\begin{array}{c}0.373^{* * *} \\
(0.112)\end{array}$ \\
\hline West Anatolia & & & & & $\begin{array}{c}-0.686^{* * * *} \\
(0.102)\end{array}$ & $\begin{array}{c}-0.686^{* * *} \\
(0.102)\end{array}$ & $\begin{array}{c}-0.676^{* * *} \\
(0.100)\end{array}$ \\
\hline Mediterranean & & & & & $\begin{array}{l}-0.037 \\
(0.099)\end{array}$ & $\begin{array}{l}-0.037 \\
(0.099)\end{array}$ & $\begin{array}{l}-0.029 \\
(0.099)\end{array}$ \\
\hline Central Anatolia & & & & & $\begin{array}{c}0.105 \\
(0.122)\end{array}$ & $\begin{array}{c}0.105 \\
(0.122)\end{array}$ & $\begin{array}{c}0.120 \\
(0.122)\end{array}$ \\
\hline West Black Sea & & & & & $\begin{array}{c}0.621^{* * *} \\
(0.208)\end{array}$ & $\begin{array}{c}0.621^{* * *} \\
(0.209)\end{array}$ & $\begin{array}{c}0.628^{* * *} \\
(0.205)\end{array}$ \\
\hline East Black Sea & & & & & $\begin{array}{c}0.359^{*} \\
(0.213)\end{array}$ & $\begin{array}{l}0.359^{*} \\
(0.213)\end{array}$ & $\begin{array}{l}0.352^{*} \\
(0.209)\end{array}$ \\
\hline Northeast Anatolia & & & & & $\begin{array}{c}0.056 \\
(0.225)\end{array}$ & $\begin{array}{c}0.056 \\
(0.226)\end{array}$ & $\begin{array}{c}0.072 \\
(0.228)\end{array}$ \\
\hline Central East Anatolia & & & & & $\begin{array}{l}-0.172 \\
(0.140)\end{array}$ & $\begin{array}{l}-0.171 \\
(0.141)\end{array}$ & $\begin{array}{l}-0.184 \\
(0.139)\end{array}$ \\
\hline Southeast Anatolia & & & & & $\begin{array}{c}0.096 \\
(0.199)\end{array}$ & $\begin{array}{c}0.097 \\
(0.199)\end{array}$ & $\begin{array}{c}0.096 \\
(0.198)\end{array}$ \\
\hline Share of services & & & & & $\begin{array}{c}0.015^{* *} \\
(0.007)\end{array}$ & $\begin{array}{c}0.015^{* *} \\
(0.007)\end{array}$ & $\begin{array}{c}0.015^{* *} \\
(0.007)\end{array}$ \\
\hline$U R_{2008}$ & & & & & $\begin{array}{l}-0.010 \\
(0.014)\end{array}$ & $\begin{array}{l}-0.010 \\
(0.014)\end{array}$ & $\begin{array}{c}-0.010 \\
(0.0140)\end{array}$ \\
\hline Constant & $\begin{array}{c}-3.748^{* * *} \\
(0.771)\end{array}$ & $\begin{array}{c}-3.849^{* * *} \\
(0.861)\end{array}$ & $\begin{array}{c}-3.832^{* * *} \\
(0.880)\end{array}$ & $\begin{array}{c}-3.876^{* * *} \\
(0.876)\end{array}$ & $\begin{array}{c}-4.275^{* * *} \\
(1.131)\end{array}$ & $\begin{array}{c}-4.277^{* * *} \\
(1.125)\end{array}$ & $\begin{array}{c}-2.875^{* *} \\
(1.334)\end{array}$ \\
\hline Observations & 1,633 & 1,633 & 1,633 & 1,633 & 1,633 & 1,633 & 1,633 \\
\hline Pseudo $R^{2}$ & 0.0388 & 0.160 & 0.163 & 0.165 & 0.187 & 0.187 & 0.185 \\
\hline
\end{tabular}


Figure 2: Number of observations and female ER in 1970 by province

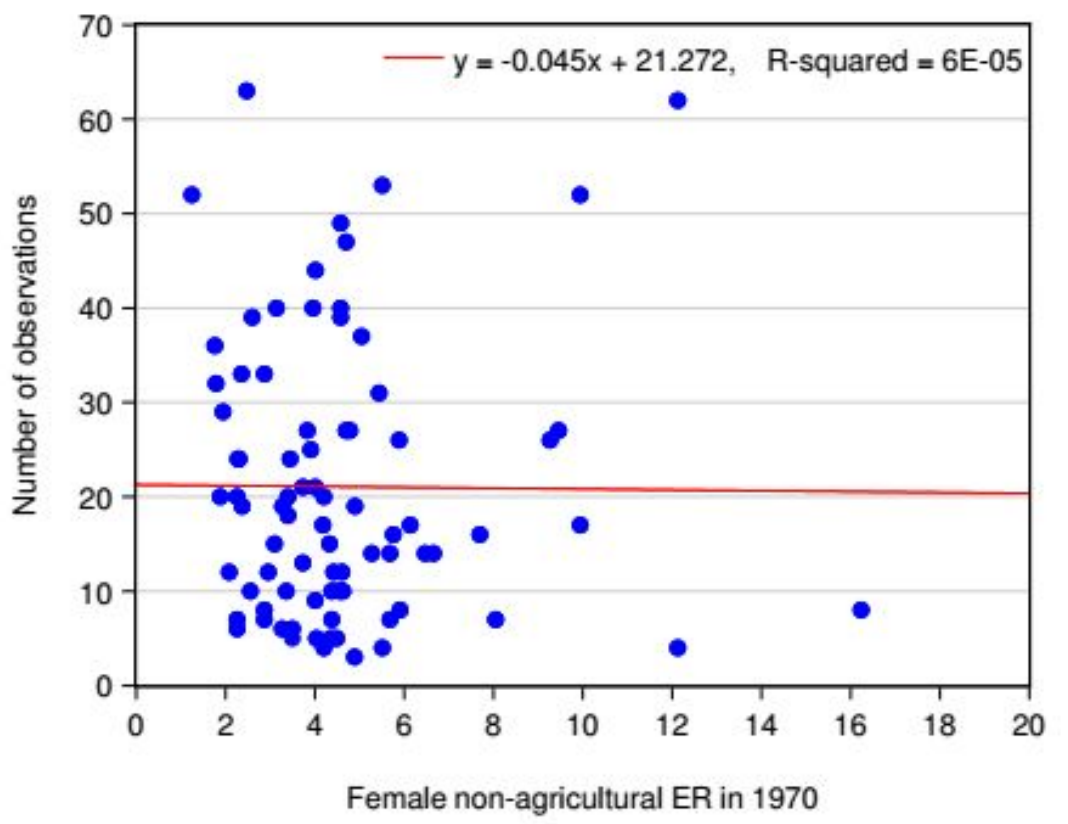

As explained above, our proxy for culture is the non-agricultural female employment rate in the province of origin for each migrant female, where the province of origin is defined as the province of primary residence until the age of 12 . We expect the female labor force participation to increase with that in province of primary residence in childhood for migrant women.

The results of the regression analysis is provided in Table 5. In our basic model, we only control for age and the female employment rate in province of origin in 1970. Since we have first-generation migrant women in our sample, we also control for age at migration. ${ }^{10}$ As expected, female labor force participation is a concave function of age. The coefficient on our instrument, i.e. female employment rate in province of origin in 1970 is positive and highly significant. In other words, higher employment rates in the province of birth in 1970 imply higher labor force participation rates in 2008 for migrant women. Labor force participation rates seem to decrease with age at migration, however, the coefficient is only significant at the $10 \%$ level.

The next step is to control for education and the number of children under the age of 5 . These are two important structural determinants of the female labor supply decision. The relationship between education and female labor force participation is straightforward. Raw data shows that labor force participation increases monotonically with education. Existing literature highlights the adverse affect of having young children on female labor force participation. These children usually do not attend any educational institutions, require personal care and as a result, decrease a woman's probability of being in labor force. ${ }^{11}$

First, note that the coefficient on our instrument is still highly significant. That is, the labor supply decisions of migrant women depend positively on the female employment rate of

people, especially women, employed in agriculture work mostly as unpaid family workers.

${ }^{10}$ Remember that $71.9 \%$ of the women in our sample are less than 40 years old.

${ }^{11}$ Preschool is neither compulsory nor widespread in Turkey. 
province of childhood residence. The rest of the results are standard. Labor force participation decreases with the number of children under the age of 5 . Labor force participation increases with education levels as expected. However, it is a cubic function of the schooling level. This should not come as a surprise as the women in the labor market in Turkey are either poorly educated or well educated. The income effect is probably strong for those with at most a high school degree whereas the substitution effect dominates for college graduates. To control for this, we include a wealth index provided in the data set. Wealth index is a composite index of consumer items (such as car, television, etc.) and living conditions (dwelling characteristics, type of drinking water, etc.). Female labor force participation is a concave function of household wealth. Note that the coefficients of variables of the previous step are still significant and highly robust to the inclusion of income and wealth indicators.

Culture may not be the only factor transmitted from parents to children that may affect female labor supply. Parental human capital may also be transmitted to the children, over and above its effect on children's education level. To control for this potential bias, we include parental education variables in the regression. Results indicate that a woman is more likely to participate in the labor market if her mother is/was literate. Note that this effect is additional to the effect of mother's non-agricultural employment, as instrumented by the female employment rate in province of childhood residence in 1970. Our findings are robust to the inclusion of parental human capital variables although the father's education does not have a significant impact.

Differences in local labor markets and institutions will affect the labor force participation decision. Therefore, we include a set of dummy variables representing region of residence as a robustness check. The omitted region is Istanbul. Clearly, regional differences persist even after we control for various characteristics. Women in East Marmara and the West Black Sea regions are more likely to participate in the labor force. On the other hand, women in East and West Anatolia, Mediterranean and the East (Northeast, Middle East and Southeast) regions are less likely to participate.

Note that Turkey is a unitary state, hence the institutional setting is uniform across different provinces. On the other hand, local labor market conditions differ considerably across regions, even across provinces. To control further for labor market differences across regions, we include two different variables in the regressions: share of services in total employment by NUTS2 and unemployment rates by province. ${ }^{12}$

Even when regional controls are added to the model, the coefficient on the female employment rates in province of childhood residence in 1970 is still significant at the $5 \%$ level. In other words, cultural effects on female labor force participation persist even when we account for differences in local labor market conditions.

We experiment with different proxies of culture to check the robustness of our results. First we consider the possibility that women who are more likely to participate today are from provinces where non-agricultural employment rates were high in 1970 . Therefore, we include male employment rates in province of origin in 1970. The results of this regression are provided in Model 6. The coefficient on female employment in 1970 is significantly positive, and that on male employment is not significantly different than zero. Clearly, it is the female employment rates and not male employment rates in the province of origin in 1970 that affects women's labor force participation in 2008.

To control for possible differences in levels across different provinces in 1970, we also use

\footnotetext{
${ }^{12}$ Non-agricultural unemployment rates are only available at the NUTS2 level. The results are quantitatively and qualitatively similar.
} 
the gender gap in non-agricultural employment rates in 1970. Coefficients of Model 7 indicate that the gender gap in employment rates in 1970 is also a good proxy for culture. Female labor force participation in 2008 increases with the gender gap in employment rates in 1970 in the province of origin. Note that the coefficients on other controls are highly robust to these robustness checks.

\subsection{Religiosity and female labor supply}

As a last experiment, we focus on a completely different potential proxy of attitudes towards women's work, i.e. religiosity. As summarized in Section 2, previous research has shown that religion may affect economic attitudes and hence women's labor supply. More specifically, individuals who practice more tend to hold a more conservative view of family life and have a less favorable attitude towards women's work.

We expand our analysis in this section to include a measure of religiosity. However, our estimation strategy still carries the flavor of the epidemiological approach. In other words, rather than controlling for current measures of religiosity, we control the previous generation's religiosity in province of origin. Our proxy for religiosity is based on electoral votes in the 1973 elections in a woman's province of origin. In absence of data on parental religiosity, we include data on electoral votes in province of origin in 1973 elections assuming that religiosity gets transmitted from one generation to the next. In this respect, we assume that religion and religious practices are an element of culture. Table 7 presents the results of this exercise along with the previous ones.

The three parties that we focus on are Republican People's Party (CHP), The Justice Party (AP) and National Salvation Party (MSP). These three parties got the highest share of votes in 1973 elections. The first two, CHP and AP, were mass parties at the time, and both had wide electoral bases. According to Sarıbay (1985), MSP, on the other hand, was the first party to enter the elections with a clear Islamist agenda according. Toprak (1984) states that "MSP considered the establishment of a powerful Muslim nation as its major goal (...) The MSP, then, advocated the reaffirmation of a Muslim way of life". MSP "argued further that the state was responsible for promoting moral development" as discussed in Heper (2002).

Regression results show that the share of CHP votes and the share of AP votes in 1973 in the province of origin do not significantly explain the female labor force participation of migrant women in 2008. Note that both of these parties were mass parties and that their share of votes were more uniformly distributed across different groups in the population. However, the coefficient on MSP's share in the 1973 elections is significantly negative. In other words, the higher the share of votes of MSP in 1973 in the province of origin, the less likely that a woman who migrated from that province would participate in the labor force in 2008 . This finding indicates that religiosity has an effect on attitudes towards women's work. Moreover, religion and religious practices may constitute an element of culture.

As a last exercise, we include our culture proxy, i.e. the female employment rates in 1970 in province of origin as well as our religiosity variable, i.e. the share of party votes in 1973 elections in province of origin in our regressions. The results are striking. The coefficients on both the culture proxy and the religiosity proxy remain significant. Furthermore, the coefficients on other controls are robust. Neither the signs nor the magnitudes of the coefficients change much. This finding further supports our results above. The culture proxy and the religiosity proxy seem to capture separate, but important effects on female labor supply decisions. 
Table 6: Share of party votes (percent, 1970)

\begin{tabular}{|c|c|c|c|c|c|c|c|c|c|}
\hline Code & City & MSP & $\mathrm{CHP}$ & $\mathrm{AP}$ & Code & City & MSP & $\mathrm{CHP}$ & $\mathrm{AP}$ \\
\hline 1 & Adana & 8.2 & 39.8 & 23.1 & 42 & Konya & 16.5 & 20.9 & 13.5 \\
\hline 2 & Adiyaman & 22.1 & 32.7 & 28.7 & 43 & Kütahya & 14.3 & 17.4 & 43 \\
\hline 3 & Afyon & 16.4 & 19.1 & 36.2 & 44 & Malatya & 19.9 & 44.1 & 13.8 \\
\hline 4 & Ă̆r1 & 14.8 & 15.5 & 15.5 & 45 & Manisa & 9.3 & 31.4 & 42.3 \\
\hline 5 & Amasya & 17.8 & 28.1 & 25.8 & 46 & Maraş & 26.7 & 32.9 & 17.9 \\
\hline 6 & Ankara & 9.3 & 41.9 & 27.8 & 47 & Mardin & 12.1 & 17.7 & 18.8 \\
\hline 7 & Antalya & 5.6 & 29.5 & 39.2 & 48 & Muğla & 3.6 & 35.2 & 36.2 \\
\hline 8 & Artvin & 7.9 & 43.7 & 34.3 & 49 & Muş & 14.7 & 17.3 & 9.4 \\
\hline 9 & Aydın & 3 & 30.1 & 34.7 & 50 & Nevşehir & 18.4 & 26 & 35.4 \\
\hline 10 & Balıkesir & 8.6 & 32.1 & 47.1 & 51 & Niğgde & 11.4 & 22.4 & 25.3 \\
\hline 11 & Bilecik & 14.4 & 31.7 & 44 & 52 & Ordu & 7.3 & 29.9 & 15.8 \\
\hline 12 & Bingöl & 25.5 & 23.3 & 20.6 & 53 & Rize & 21.9 & 31.1 & 29.7 \\
\hline 13 & Bitlis & 11.3 & 15.5 & 40.6 & 54 & Sakarya & 18.2 & 24.7 & 29.3 \\
\hline 14 & Bolu & 17.3 & 15.3 & 41.3 & 55 & Samsun & 13.4 & 30.7 & 38.3 \\
\hline 15 & Burdur & 9.3 & 30.8 & 25.6 & 56 & Siirt & 9.5 & 14.2 & 16.4 \\
\hline 16 & Bursa & 9.4 & 28 & 50.7 & 57 & Sinop & 7.7 & 30.8 & 24.7 \\
\hline 17 & Çanakkale & 5.5 & 35.6 & 44.2 & 58 & Sivas & 25.7 & 32.9 & 16.9 \\
\hline 18 & Çankırı & 16.3 & 14.5 & 38.7 & 59 & Tekirdă̆ & 3.3 & 34.4 & 40.2 \\
\hline 19 & Çorum & 21.7 & 30.7 & 19 & 60 & Tokat & 18.2 & 29.8 & 19.3 \\
\hline 20 & Denizli & 5.3 & 33.5 & 33.9 & 61 & Trabzon & 15.1 & 35 & 25.1 \\
\hline 21 & Diyarbakır & 18.5 & 30.4 & 20.7 & 62 & Tunceli & 2.6 & 70 & 14.3 \\
\hline 22 & Edirne & 2.2 & 44.2 & 41.6 & 63 & Şanlıurfa & 17.6 & 29 & 33.5 \\
\hline 23 & Elazığ & 27.8 & 29.5 & 25.5 & 64 & Uşak & 6.7 & 39 & 33 \\
\hline 24 & Erzincan & 16.1 & 45.3 & 25.6 & 65 & Van & 7 & 10.3 & 22.4 \\
\hline 25 & Erzurum & 29.5 & 19.7 & 22.9 & 66 & Yozgat & 21.5 & 27 & 17.5 \\
\hline 26 & Eskişehir & 9.2 & 31.9 & 40.6 & 67 & Zonguldak & 8.2 & 39.8 & 38.2 \\
\hline 27 & Gaziantep & 11.6 & 37 & 17.7 & 68 & Aksaray & 11.7 & 16.7 & 18.4 \\
\hline 28 & Giresun & 8.7 & 31.7 & 27.3 & 69 & Bayburt & 39 & 23.4 & 24.2 \\
\hline 29 & Gümüşhane & 24.9 & 19.5 & 36.5 & 70 & Karaman & 11.8 & 24.2 & 12.3 \\
\hline 30 & Hakkari & 2.1 & 35.4 & 33 & 71 & Kırıkkale & 10.4 & 30.8 & 21.2 \\
\hline 31 & Hatay & 6.4 & 37.5 & 23.3 & 72 & Batman & 26.5 & 12.4 & 3.6 \\
\hline 32 & Isparta & 7.1 & 14.4 & 62.1 & 73 & Şırnak & 5.9 & 27.3 & 24.7 \\
\hline 33 & İçel & 2.8 & 39.2 & 29.4 & 74 & Bartın & 7.1 & 35.8 & 38.8 \\
\hline 34 & İstanbul & 8.4 & 48.9 & 28.5 & 75 & Ardahan & 8.3 & 57.6 & 10 \\
\hline 35 & İzmir & 4.2 & 44.1 & 39.3 & 76 & Iğdır & 1.9 & 29.4 & 16 \\
\hline 36 & Kars & 7.8 & 45.5 & 15 & 77 & Yalova & 4.6 & 40.9 & 38.2 \\
\hline 37 & Kastamonu & 6 & 21.4 & 39 & 78 & Karabük & 17.4 & 28.3 & 38.5 \\
\hline 38 & Kayseri & 16.5 & 23.3 & 27.3 & 79 & Kilis & 16.5 & 29.4 & 16.5 \\
\hline 39 & Kırklareli & 2.6 & 43.7 & 42 & 80 & Osmaniye & 10.1 & 29.5 & 27.9 \\
\hline 40 & Kırşehir & 13.8 & 31.1 & 14.1 & 81 & Düzce & 18.8 & 13.8 & 36.5 \\
\hline 41 & Kocaeli & 18.1 & 33.6 & 32.3 & & & & & \\
\hline
\end{tabular}

Source: Supreme Electoral Council of Turkey, 1973 General Elections 
Table 7: Estimation results - 1973 Elections

\begin{tabular}{|c|c|c|c|}
\hline & (5) & (8) & (9) \\
\hline Female $E R_{1970}$ & $\begin{array}{c}0.043^{* * *} \\
(0.017)\end{array}$ & & $\begin{array}{c}0.034^{*} \\
(0.019)\end{array}$ \\
\hline MSP & & $\begin{array}{c}-0.013^{* *} \\
(0.005)\end{array}$ & $\begin{array}{c}-0.012^{* *} \\
(0.006)\end{array}$ \\
\hline $\mathrm{CHP}$ & & $\begin{array}{c}0.004 \\
(0.004)\end{array}$ & $\begin{array}{c}0.003 \\
(0.004)\end{array}$ \\
\hline $\mathrm{AP}$ & & $\begin{array}{c}0.002 \\
(0.005)\end{array}$ & $\begin{array}{c}0.000 \\
(0.005)\end{array}$ \\
\hline Age & $\begin{array}{c}0.152^{* * *} \\
(0.056)\end{array}$ & $\begin{array}{c}0.152^{* * *} * \\
(0.057)\end{array}$ & $\begin{array}{c}0.153^{* * *} \\
(0.055)\end{array}$ \\
\hline Age squared & $\begin{array}{c}-0.002^{* *} \\
(0.001)\end{array}$ & $\begin{array}{c}-0.002^{* *} \\
(0.001)\end{array}$ & $\begin{array}{c}-0.002^{* *} \\
(0.001)\end{array}$ \\
\hline Age at migration & $\begin{array}{l}-0.005 \\
(0.006)\end{array}$ & $\begin{array}{l}-0.004 \\
(0.006)\end{array}$ & $\begin{array}{l}-0.005 \\
(0.006)\end{array}$ \\
\hline Schooling & $\begin{array}{c}0.138 * * \\
(0.068)\end{array}$ & $\begin{array}{c}0.138^{* *} \\
(0.066)\end{array}$ & $\begin{array}{c}0.135^{* *} \\
(0.067)\end{array}$ \\
\hline Schooling squared & $\begin{array}{c}-0.028^{* *} \\
(0.011)\end{array}$ & $\begin{array}{c}-0.028^{* *} \\
(0.011)\end{array}$ & $\begin{array}{c}-0.029^{* *} \\
(0.011)\end{array}$ \\
\hline Schooling cubed & $\begin{array}{c}0.002^{* * *} \\
(0.001)\end{array}$ & $\begin{array}{c}0.002^{* * * *} \\
(0.001)\end{array}$ & $\begin{array}{c}0.002^{* * *} \\
(0.001)\end{array}$ \\
\hline Number of children under 5 & $\begin{array}{c}-0.172^{* *} \\
(0.078)\end{array}$ & $\begin{array}{c}-0.173^{* *} \\
(0.077)\end{array}$ & $\begin{array}{c}-0.171^{* *} \\
(0.077)\end{array}$ \\
\hline Wealth index & $\begin{array}{c}0.096 \\
(0.081)\end{array}$ & $\begin{array}{c}0.105 \\
(0.080)\end{array}$ & $\begin{array}{c}0.100 \\
(0.080)\end{array}$ \\
\hline Wealth index squared & $\begin{array}{c}-0.094^{*} \\
(0.054)\end{array}$ & $\begin{array}{c}-0.097^{*} \\
(0.053)\end{array}$ & $\begin{array}{c}-0.100^{*} \\
(0.054)\end{array}$ \\
\hline Mother literate & $\begin{array}{c}0.184^{* *} \\
(0.087)\end{array}$ & $\begin{array}{c}0.183^{* *} \\
(0.091)\end{array}$ & $\begin{array}{l}0.171^{*} \\
(0.092)\end{array}$ \\
\hline Father literate & $\begin{array}{l}-0.118 \\
(0.112)\end{array}$ & $\begin{array}{l}-0.108 \\
(0.116)\end{array}$ & $\begin{array}{l}-0.116 \\
(0.114)\end{array}$ \\
\hline West Marmara & $\begin{array}{c}0.221 \\
(0.154)\end{array}$ & $\begin{array}{c}0.221 \\
(0.160)\end{array}$ & $\begin{array}{c}0.203 \\
(0.153)\end{array}$ \\
\hline Aegean & $\begin{array}{c}0.258^{* * *} \\
(0.087)\end{array}$ & $\begin{array}{c}0.284^{* * *} * \\
(0.084)\end{array}$ & $\begin{array}{c}0.261^{* * *} \\
(0.086)\end{array}$ \\
\hline East Marmara & $\begin{array}{c}0.357^{* * *} \\
(0.112)\end{array}$ & $\begin{array}{c}0.392^{* * *} \\
(0.117)\end{array}$ & $\begin{array}{c}0.382^{* * *} \\
(0.116)\end{array}$ \\
\hline West Anatolia & $\begin{array}{c}-0.686^{* * *} \\
(0.102)\end{array}$ & $\begin{array}{c}-0.666^{* * *} \\
(0.110)\end{array}$ & $\begin{array}{c}-0.674^{* * *} \\
(0.100)\end{array}$ \\
\hline Mediterranean & $\begin{array}{l}-0.037 \\
(0.010)\end{array}$ & $\begin{array}{l}-0.007 \\
(0.108)\end{array}$ & $\begin{array}{c}-0.023 \\
(0.106)\end{array}$ \\
\hline Central Anatolia & $\begin{array}{c}0.105 \\
(0.122)\end{array}$ & $\begin{array}{c}0.212 \\
(0.132)\end{array}$ & $\begin{array}{c}0.168 \\
(0.138)\end{array}$ \\
\hline West Black Sea & $\begin{array}{c}0.621^{* * *} \\
(0.208)\end{array}$ & $\begin{array}{c}0.611^{* * *} * \\
(0.214)\end{array}$ & $\begin{array}{c}0.604^{* * *} \\
(0.211)\end{array}$ \\
\hline East Black Sea & $\begin{array}{l}0.359^{*} \\
(0.213)\end{array}$ & $\begin{array}{l}0.397^{*} \\
(0.218)\end{array}$ & $\begin{array}{c}0.384^{*} \\
(0.215)\end{array}$ \\
\hline Northeast Anatolia & $\begin{array}{c}0.057 \\
(0.225)\end{array}$ & $\begin{array}{c}0.045 \\
(0.239)\end{array}$ & $\begin{array}{c}0.036 \\
(0.232)\end{array}$ \\
\hline Central East Anatolia & $\begin{array}{l}-0.171 \\
(0.140)\end{array}$ & $\begin{array}{l}-0.165 \\
(0.148)\end{array}$ & $\begin{array}{c}-0.152 \\
(0.149)\end{array}$ \\
\hline Southeast Anatolia & $\begin{array}{c}0.097 \\
(0.199)\end{array}$ & $\begin{array}{c}0.135 \\
(0.212)\end{array}$ & $\begin{array}{c}0.123 \\
(0.207)\end{array}$ \\
\hline Share of services & $\begin{array}{c}0.015 * * \\
(0.007)\end{array}$ & $\begin{array}{c}0.016^{* *} \\
(0.008)\end{array}$ & $\begin{array}{c}0.015^{* *} \\
(0.008)\end{array}$ \\
\hline$U R_{2008}$ & $\begin{array}{l}-0.010 \\
(0.014)\end{array}$ & $\begin{array}{l}-0.013 \\
(0.014)\end{array}$ & $\begin{array}{l}-0.012 \\
(0.014)\end{array}$ \\
\hline Constant & $\begin{array}{c}-4.283^{* * *} \\
(1.129)\end{array}$ & $\begin{array}{c}-4.114^{* * *} \\
(1.237)\end{array}$ & $\begin{array}{c}-4.172^{* * *} \\
(1.200)\end{array}$ \\
\hline Observations & 1,633 & 1,633 & 1,633 \\
\hline Pseudo $R^{2}$ & 0.187 & 0.188 & 0.190 \\
\hline
\end{tabular}




\subsection{Marginal Effects}

Clearly, the marginal effects of different factors that affect female labor force participation decisions are needed to quantify the effects of culture in this decision. The computed marginal effects are provided in Table 8. We will discuss the first column, i.e. the marginal effects of the regression where the non-agricultural employment rates in 1970 constitute the cultural proxy, however, the marginal effects, like the coefficients, are robust across different controls of culture.

One standard deviation increase in non-agricultural employment rates in 1970 (2.6 percentage points), increases the probability that a woman will participate by 3 percent. Clearly, culture has a strong and sizeable effect on female labor force participation. One standard deviation increase in MSP votes in 1973 (7.6 percentage points), decreases the probability that a woman will participate by 3 percent as well.

When proxies for culture and religiosity are included simultaneously in the model, the marginal effect of a one standard deviation increase in the culture proxy increases the female labor force participation in 2008 by 2.34 percent. The marginal effect of the religiosity proxy is similar in magnitude at 2.28 percent.

The marginal effects of other controls are similar in magnitude across different models, hence we only focus on the last column, i.e. on the most extensive model we consider. Increasing education levels will also help increase female labor force participation in Turkey. The results show that having an extra year of schooling increases the probability that a woman will participate in the labor force by 3.7 percent. Given the increase in compulsory years of schooling from 5 to 8 years, we should expect female LFPR to soar in the upcoming years. Also, the regression results show that the effects of any increase in women's education levels will have intergenerational effects. Note that the marginal effect of having a literate mother is 4.8 percent. Having one more child below the age of 5 decreases the labor force participation probability by 4.7 percent. This finding indicates that women's child care responsibilities hinder female labor force participation in Turkey and that policies aiming at expanding child care opportunities may go a long way in increasing female labor force participation.

\subsection{How good are the cultural proxies?}

Recall that culture is defined as a set of beliefs and preferences that vary systematically across groups of individuals separated by space or time. By using culture proxies at the birth province level, we assume a priori that culture is shared by residents of a province, at least to a certain extent if not completely. If so, measuring culture at the provincial level is not a very restrictive assumption. Even though regression results clearly show that our culture variables are good proxies of cultural variation at the birth province level, our proxies represent only certain aspects of culture. In order to see how good our proxies are at capturing the province level variation in culture, we perform an additional exercise. First, we replicate the participation regression using province of birth dummies instead of the cultural proxies(Table 9).

Note that using province dummies do not change the coefficient estimates of other covariates and overall explanatory power of the model slightly increases. We, then, regress the coefficient estimates of the dummy set on our culture proxies. Results are given in Table 10. The coefficients on our two proxies, namely the female employment rate in $1970\left(E R_{1970 a}\right)$ and vote shares in the 1973 Elections (MSP), are significant and have the expected sign. In other words, the coefficients on province dummies are positively correlated with our cultural proxy of female employment rates in 1970 and negatively correlated with our religiosity proxy of share 
Table 8: Marginal Effects

\begin{tabular}{|c|c|c|c|}
\hline & $(5)$ & $(8)$ & (9) \\
\hline Female $E R_{1970}$ & $\begin{array}{c}0.012^{* * * *} \\
(0.005)\end{array}$ & & $\begin{array}{c}0.009^{*} \\
(0.005)\end{array}$ \\
\hline MSP & & $\begin{array}{c}-0.004^{* * *} \\
(0.001)\end{array}$ & $\begin{array}{c}-0.003^{* *} \\
(0.002)\end{array}$ \\
\hline CHP & & $\begin{array}{c}0.001 \\
(0.001)\end{array}$ & $\begin{array}{c}0.001 \\
(0.001)\end{array}$ \\
\hline $\mathrm{AP}$ & & $\begin{array}{c}0.001 \\
(0.001)\end{array}$ & $\begin{array}{c}0.000 \\
(0.001)\end{array}$ \\
\hline Current age & $\begin{array}{c}0.002 \\
(0.002)\end{array}$ & $\begin{array}{c}0.002 \\
(0.002)\end{array}$ & $\begin{array}{c}0.002 \\
(0.002)\end{array}$ \\
\hline Age at migration & $\begin{array}{l}-0.001 \\
(0.002)\end{array}$ & $\begin{array}{l}-0.001 \\
(0.002)\end{array}$ & $\begin{array}{l}-0.001 \\
(0.002)\end{array}$ \\
\hline Schooling & $\begin{array}{c}0.028^{* * *} * \\
(0.003)\end{array}$ & $\begin{array}{c}0.028^{* * *} \\
(0.003)\end{array}$ & $\begin{array}{c}0.027^{* * *} \\
(0.003)\end{array}$ \\
\hline Number of children 5 and under & $\begin{array}{c}-0.047^{* *} \\
(0.021)\end{array}$ & $\begin{array}{c}-0.048^{* *} \\
(0.021)\end{array}$ & $\begin{array}{c}-0.047^{* *} \\
(0.021)\end{array}$ \\
\hline Wealth index & $\begin{array}{l}-0.004 \\
(0.015)\end{array}$ & $\begin{array}{l}-0.002 \\
(0.015)\end{array}$ & $\begin{array}{l}-0.004 \\
(0.015)\end{array}$ \\
\hline Mother literate & $\begin{array}{c}0.051^{* *} \\
(0.024)\end{array}$ & $\begin{array}{c}0.051^{* *} \\
(0.025)\end{array}$ & $\begin{array}{l}0.047^{*} \\
(0.025)\end{array}$ \\
\hline Father literate & $\begin{array}{l}-0.033 \\
(0.031)\end{array}$ & $\begin{array}{l}-0.030 \\
(0.031)\end{array}$ & $\begin{array}{l}-0.032 \\
(0.031)\end{array}$ \\
\hline West Marmara & $\begin{array}{c}0.062 \\
(0.044)\end{array}$ & $\begin{array}{c}0.062 \\
(0.045)\end{array}$ & $\begin{array}{c}0.056 \\
(0.043)\end{array}$ \\
\hline Aegean & $\begin{array}{c}0.074^{* * * *} \\
(0.026)\end{array}$ & $\begin{array}{c}0.080^{* * *} \\
(0.025)\end{array}$ & $\begin{array}{c}0.074^{* * *} \\
(0.026)\end{array}$ \\
\hline East Marmara & $\begin{array}{c}0.104^{* * *} \\
(0.031)\end{array}$ & $\begin{array}{c}0.114^{* * *} \\
(0.032)\end{array}$ & $\begin{array}{c}0.111^{\text {*** }} \\
(0.032)\end{array}$ \\
\hline West Anatolia & $\begin{array}{c}-0.141^{* * *} \\
(0.012)\end{array}$ & $\begin{array}{c}-0.136^{* * *} \\
(0.013)\end{array}$ & $\begin{array}{c}-0.138 * * * \\
(0.012)\end{array}$ \\
\hline Mediterranean & $\begin{array}{l}-0.010 \\
(0.026)\end{array}$ & $\begin{array}{l}-0.002 \\
(0.028)\end{array}$ & $\begin{array}{c}-0.006 \\
(0.028)\end{array}$ \\
\hline Central Anatolia & $\begin{array}{c}0.029 \\
(0.034)\end{array}$ & $\begin{array}{c}0.059 \\
(0.037)\end{array}$ & $\begin{array}{c}0.046 \\
(0.038)\end{array}$ \\
\hline West Black Sea & $\begin{array}{c}0.191^{* * * *} \\
(0.066)\end{array}$ & $\begin{array}{c}0.186^{* * * *} \\
(0.067)\end{array}$ & $\begin{array}{c}0.184^{* * *} \\
(0.066)\end{array}$ \\
\hline East Black Sea & $\begin{array}{c}0.105 \\
(0.065)\end{array}$ & $\begin{array}{l}0.116^{*} \\
(0.066)\end{array}$ & $\begin{array}{l}0.112^{*} \\
(0.065)\end{array}$ \\
\hline Northeast Anatolia & $\begin{array}{c}0.015 \\
(0.061)\end{array}$ & $\begin{array}{c}0.012 \\
(0.064)\end{array}$ & $\begin{array}{c}0.010 \\
(0.062)\end{array}$ \\
\hline Central East Anatolia & $\begin{array}{l}-0.043 \\
(0.034)\end{array}$ & $\begin{array}{l}-0.041 \\
(0.035)\end{array}$ & $\begin{array}{l}-0.038 \\
(0.036)\end{array}$ \\
\hline Southeast Anatolia & $\begin{array}{c}0.027 \\
(0.055)\end{array}$ & $\begin{array}{c}0.037 \\
(0.059)\end{array}$ & $\begin{array}{c}0.033 \\
(0.058)\end{array}$ \\
\hline Share of services & $\begin{array}{c}0.004^{* *} \\
(0.002)\end{array}$ & $\begin{array}{c}0.004^{* *} \\
(0.002)\end{array}$ & $\begin{array}{c}0.004^{* *} \\
(0.002)\end{array}$ \\
\hline$U R_{2008}$ & $\begin{array}{l}-0.003 \\
(0.004)\end{array}$ & $\begin{array}{l}-0.004 \\
(0.004)\end{array}$ & $\begin{array}{l}-0.003 \\
(0.004)\end{array}$ \\
\hline Observations & 1633 & 1633 & 1633 \\
\hline Pseudo $R^{2}$ & 0.187 & 0.188 & 0.19 \\
\hline
\end{tabular}


Table 9: Estimation results - Province of birth dummy set

\begin{tabular}{|c|c|c|c|c|}
\hline & (1) & $(2)$ & $(5)$ & (6) \\
\hline $\begin{array}{l}\text { CULTURE } \\
\text { PROXIES }\end{array}$ & $\begin{array}{l}\text { Female employment } \\
\text { rate in } 1970\end{array}$ & $\begin{array}{l}\text { Gender gap in emp. } \\
\text { rates in } 1970\end{array}$ & $\begin{array}{c}\text { Political party vote } \\
\text { shares in } 1973 \text { Elections }\end{array}$ & $\begin{array}{l}\text { Birth province } \\
\text { dummies }\end{array}$ \\
\hline Current age & $\begin{array}{c}0.151^{* * *} \\
(0.056)\end{array}$ & $\begin{array}{c}0.149^{* * *} \\
(0.056)\end{array}$ & $\begin{array}{c}0.150^{* * *} \\
(0.057)\end{array}$ & $\begin{array}{c}0.164^{* * *} \\
(0.063)\end{array}$ \\
\hline Age squared & $\begin{array}{c}-0.002^{* *} \\
(0.001)\end{array}$ & $\begin{array}{c}-0.002^{* *} \\
(0.001)\end{array}$ & $\begin{array}{c}-0.002^{* *} \\
(0.001)\end{array}$ & $\begin{array}{c}-0.002^{* *} \\
(0.001)\end{array}$ \\
\hline Age at migration & $\begin{array}{l}-0.005 \\
(0.006)\end{array}$ & $\begin{array}{l}-0.005 \\
(0.006)\end{array}$ & $\begin{array}{l}-0.005 \\
(0.006)\end{array}$ & $\begin{array}{l}-0.009 \\
(0.006)\end{array}$ \\
\hline Schooling & $\begin{array}{c}0.139^{* *} \\
(0.068)\end{array}$ & $\begin{array}{c}0.142^{* *} \\
(0.068)\end{array}$ & $\begin{array}{c}0.138^{* *} \\
(0.066)\end{array}$ & $\begin{array}{c}0.134^{* *} \\
(0.068)\end{array}$ \\
\hline Schooling squared & $\begin{array}{c}-0.028^{* *} \\
(0.011)\end{array}$ & $\begin{array}{c}-0.028^{* *} \\
(0.011)\end{array}$ & $\begin{array}{c}-0.028^{* * *} \\
(0.011)\end{array}$ & $\begin{array}{c}-0.031^{* *} \\
(0.012)\end{array}$ \\
\hline Schooling cubed & $\begin{array}{c}0.002^{* * *} \\
(0.001)\end{array}$ & $\begin{array}{c}0.002^{* * *} \\
(0.001)\end{array}$ & $\begin{array}{c}0.002^{* * *} \\
(0.001)\end{array}$ & $\begin{array}{c}0.002^{* * *} \\
(0.001)\end{array}$ \\
\hline Number of children under 5 & $\begin{array}{c}-0.173^{* *} \\
(0.078)\end{array}$ & $\begin{array}{c}-0.183^{* *} \\
(0.078)\end{array}$ & $\begin{array}{c}-0.170^{* *} \\
(0.079)\end{array}$ & $\begin{array}{c}-0.187^{* *} \\
(0.076)\end{array}$ \\
\hline Wealth index & $\begin{array}{c}0.096 \\
(0.081)\end{array}$ & $\begin{array}{l}0.088 \\
(0.080)\end{array}$ & $\begin{array}{c}0.126 \\
(0.078)\end{array}$ & $\begin{array}{l}0.106 \\
(0.087)\end{array}$ \\
\hline Wealth index squared & $\begin{array}{l}-0.094^{*} \\
(0.054)\end{array}$ & $\begin{array}{l}-0.086 \\
(0.053)\end{array}$ & $\begin{array}{c}-0.108^{* *} \\
(0.052)\end{array}$ & $\begin{array}{l}-0.110^{*} \\
(0.057)\end{array}$ \\
\hline Mother literate & $\begin{array}{c}0.184^{* *} \\
(0.087)\end{array}$ & $\begin{array}{c}0.210^{* *} \\
(0.086)\end{array}$ & $\begin{array}{c}0.192^{* *} \\
(0.091)\end{array}$ & $\begin{array}{c}0.207^{* *} \\
(0.089)\end{array}$ \\
\hline Father literate & $\begin{array}{l}-0.119 \\
(0.111)\end{array}$ & $\begin{array}{l}-0.117 \\
(0.110)\end{array}$ & $\begin{array}{l}-0.120 \\
(0.109)\end{array}$ & $\begin{array}{l}-0.116 \\
(0.115)\end{array}$ \\
\hline West Marmara & $\begin{array}{c}0.221 \\
(0.154)\end{array}$ & $\begin{array}{c}0.246 \\
(0.157)\end{array}$ & $\begin{array}{c}0.254 \\
(0.167)\end{array}$ & $\begin{array}{c}0.208 \\
(0.169)\end{array}$ \\
\hline Aegean & $\begin{array}{c}0.258^{* * *} \\
(0.087)\end{array}$ & $\begin{array}{c}0.267^{* * *} \\
(0.084)\end{array}$ & $\begin{array}{c}0.280^{* * *} \\
(0.090)\end{array}$ & $\begin{array}{c}0.228^{*} \\
(0.125)\end{array}$ \\
\hline East Marmara & $\begin{array}{c}0.357^{* * *} \\
(0.112)\end{array}$ & $\begin{array}{c}0.373^{* * *} \\
(0.112)\end{array}$ & $\begin{array}{c}0.392^{* * *} \\
(0.120)\end{array}$ & $\begin{array}{c}0.452^{* * *} \\
(0.151)\end{array}$ \\
\hline West Anatolia & $\begin{array}{c}-0.686^{* * *} \\
(0.102)\end{array}$ & $\begin{array}{c}-0.676^{* * *} \\
(0.0998)\end{array}$ & $\begin{array}{c}-0.680^{* * *} \\
(0.114)\end{array}$ & $\begin{array}{c}-0.734^{* * *} \\
(0.134)\end{array}$ \\
\hline Mediterranean & $\begin{array}{l}-0.037 \\
(0.099)\end{array}$ & $\begin{array}{l}-0.029 \\
(0.099)\end{array}$ & $\begin{array}{l}-0.008 \\
(0.112)\end{array}$ & $\begin{array}{l}-0.045 \\
(0.105)\end{array}$ \\
\hline Central Anatolia & $\begin{array}{c}0.105 \\
(0.122)\end{array}$ & $\begin{array}{c}0.120 \\
(0.122)\end{array}$ & $\begin{array}{c}0.161 \\
(0.136)\end{array}$ & $\begin{array}{c}0.193 \\
(0.178)\end{array}$ \\
\hline West Black Sea & $\begin{array}{c}0.621 * * * \\
(0.208)\end{array}$ & $\begin{array}{c}0.628^{* * *} \\
(0.205)\end{array}$ & $\begin{array}{c}0.659^{* * * *} \\
(0.224)\end{array}$ & $\begin{array}{c}0.689^{* * * *} \\
(0.235)\end{array}$ \\
\hline East Black Sea & $\begin{array}{l}0.359^{*} \\
(0.213)\end{array}$ & $\begin{array}{l}0.352^{*} \\
(0.209)\end{array}$ & $\begin{array}{c}0.389^{*} \\
(0.228)\end{array}$ & $\begin{array}{c}0.505^{* *} \\
(0.247)\end{array}$ \\
\hline Northeast Anatolia & $\begin{array}{c}0.056 \\
(0.225)\end{array}$ & $\begin{array}{c}0.072 \\
(0.228)\end{array}$ & $\begin{array}{c}0.022 \\
(0.253)\end{array}$ & $\begin{array}{c}0.107 \\
(0.241)\end{array}$ \\
\hline Central East Anatolia & $\begin{array}{l}-0.172 \\
(0.140)\end{array}$ & $\begin{array}{l}-0.184 \\
(0.139)\end{array}$ & $\begin{array}{l}-0.166 \\
(0.149)\end{array}$ & $\begin{array}{l}-0.119 \\
(0.201)\end{array}$ \\
\hline Southeast Anatolia & $\begin{array}{c}0.096 \\
(0.199)\end{array}$ & $\begin{array}{c}0.096 \\
(0.198)\end{array}$ & $\begin{array}{c}0.127 \\
(0.215)\end{array}$ & $\begin{array}{l}0.115 \\
(0.244)\end{array}$ \\
\hline Share of services & $\begin{array}{c}0.015^{* *} \\
(0.007)\end{array}$ & $\begin{array}{c}0.015^{* *} \\
(0.007)\end{array}$ & $\begin{array}{c}0.017^{* *} \\
(0.008)\end{array}$ & $\begin{array}{c}0.019^{* *} \\
(0.008)\end{array}$ \\
\hline$U R_{2008}$ & $\begin{array}{l}-0.010 \\
(0.014)\end{array}$ & $\begin{array}{c}-0.010 \\
(0.014)\end{array}$ & $\begin{array}{c}-0.012 \\
(0.015)\end{array}$ & $\begin{array}{l}-0.010 \\
(0.019)\end{array}$ \\
\hline Constant & $\begin{array}{c}-4.275^{* * *} \\
(1.131)\end{array}$ & $\begin{array}{c}-2.875^{* *} \\
(1.334)\end{array}$ & $\begin{array}{c}-4.116^{* * *} \\
(1.289)\end{array}$ & $\begin{array}{c}-4.440^{* * *} \\
(1.212)\end{array}$ \\
\hline Observations & 1,633 & 1,633 & 1,624 & 1,579 \\
\hline Pseudo $R^{2}$ & 0.187 & 0.185 & 0.189 & 0.224 \\
\hline
\end{tabular}


of MSP votes in 1973. On the other hand, neither the male employment rates in 1970 nor the share of mass party votes in 1973 have significant coefficients. Overall our proxies are able to explain one tenth of the variation in coefficients of province dummies.

Table 10: Estimation results

\begin{tabular}{|c|c|c|c|c|}
\hline Culture Proxies & Model I & Model II & Model III & Model IV \\
\hline$E R_{1970}$ & $\begin{array}{c}0.049^{* * *} \\
(0.017)\end{array}$ & & $\begin{array}{c}0.040^{* *} \\
(0.018)\end{array}$ & $\begin{array}{c}0.044^{* *} \\
(0.021)\end{array}$ \\
\hline MSP & & $\begin{array}{c}-0.017^{* *} \\
(0.007)\end{array}$ & $\begin{array}{c}-0.015^{* *} \\
(0.007)\end{array}$ & $\begin{array}{c}-0.015^{* *} \\
(0.007)\end{array}$ \\
\hline CHP & & $\begin{array}{c}-0.001 \\
(0.005)\end{array}$ & $\begin{array}{c}-0.001 \\
(0.004)\end{array}$ & $\begin{array}{c}-0.001 \\
(0.005)\end{array}$ \\
\hline $\mathrm{AP}$ & & $\begin{array}{c}0.002 \\
(0.004)\end{array}$ & $\begin{array}{l}-0.001 \\
(0.004)\end{array}$ & $\begin{array}{l}-0.000 \\
(0.004)\end{array}$ \\
\hline Male $E R_{1970}$ & & & & $\begin{array}{l}-0.002 \\
(0.004)\end{array}$ \\
\hline Constant & $\begin{array}{c}-0.193^{* *} \\
(0.0895)\end{array}$ & $\begin{array}{c}0.239 \\
(0.255)\end{array}$ & $\begin{array}{c}0.101 \\
(0.256)\end{array}$ & $\begin{array}{c}0.100 \\
(0.257)\end{array}$ \\
\hline Observations & 81 & 81 & 81 & 81 \\
\hline R-squared & 0.094 & 0.104 & 0.160 & 0.161 \\
\hline
\end{tabular}

\section{Conclusion}

In this paper, we analyze the effects of culture on the female labor supply decisions by extending the epidemiological approach to an environment of widespread internal migration. We find that culture has an effect on female labor force participation decisions of migrant women in 2008, where culture is proxied by employment rates in their respective provinces of origin in 1970. The effect of culture is significant and sizeable, even when other personal characteristics, parental human capital and institutional environment is controlled for. We also include male employment rates in 1970 and the gender gap in employment rates in 1970 as robustness checks. We find that it is the female employment rate, and not the male, in province of origin in 1970 that affects the female labor force participation decision in 2008. Marginal effects indicate that one standard deviation increase in female employment rates in 1970, increases the probability that a woman will participate by 3 percent.

We also contribute to the literature on religion and economics. Currently, research in this area has mainly focused on cross-country analysis such as Guiso et al. (2003) and Algan and Cahuc (2006). Heineck (2004) studies the labor market in Germany and shows that women with stronger religious beliefs are less likely to participate in the labor market. We extend the epidemiological approach to tackle the question: "does religiosity affect the female labor supply?" We use electoral votes in 1973 elections in Turkey to build a proxy of religiosity. 1973 elections were the first elections in Turkey, in which a party, MSP, entered with a clear religious agenda. We find that religiosity affects the female labor force participation decision negatively. Controlling for a variety of different factors, we find that the migrants who come from provinces where MSP had a larger (smaller) share of the votes in 1973 are less (more) 
likely to participate in the labor force today. Shares of votes of CHP and AP, both of which are mass parties at that time, do not significantly affect female labor force participation decisions today.

Including both the cultural and the religiosity proxies in an extended model, we find that both factors have significant effects on female labor force participation decisions. That is, our culture proxy and our religiosity proxy seem to capture separate effects on female labor supply. One standard devation increase in female employment rates in 1970, increases female labor force participation by 2.34 percent; one standard deviation increase in the religious party votes in 1973 decreases female labor force participation by 2.28 percent. Note that both of these effects are over and above the intergenerational human capital transmission. Having a literate mother increases the probability that a woman will participate by 4.8 percent. Clearly, own education is also an important factor. An extra year of schooling increases participation by 3.7 percent. Conversely, an extra child under the age of 5 decreases it by 4.7 percent. These findings indicate that multidimensional policies that include education, child care opportunities for mothers with young children as well as cultural components are needed to increase female labor force participation rates. 


\section{References}

Algan, Y. and P. Cahuc (2006, Autumn). Job protection: The macho hypothesis. Oxford Review of Economic Policy 22(3), 390-410.

Algan, Y. and P. Cahuc (2010). Inherited trust and growth. American Economic Review $100(5), 2060-92$.

Antecol, H. (2000). An examination of cross-country differences in the gender gap in labor force participation rates. Labour Economics 7(4), 409-426.

Başlevent, C. and İnsan Tunalı (2005). Female labor supply in Turkey. In S. G. Altuğ and A. Filiztekin (Eds.), The Turkish Economy: The Real Economy, Corporate Governance, and Reform and Stabilization Policy, pp. 92-127. London: Routledge Curzon Studies in Middle Eastern Economics.

Bénabou, R. and J. Tirole (2006). Belief in a just world and redistributive politics. The Quarterly Journal of Economics 121(2), 699-746.

Bisin, A. and T. Verdier (2001). The economics of cultural transmission and the dynamics of preferences. Journal of Economic Theory 97(2), 298-319.

Blau, F. D., L. M. Kahn, A. Y.-H. Liu, and K. L. Papps (2008, October). The transmission of women's fertility, human capital and work orientation across immigrant generations. NBER Working Papers 14388, National Bureau of Economic Research, Inc.

Dayıoğlu, M. and M. Kırdar (2009). Determinants of and trends in labor force participation of women in Turkey. Unpublished manuscript, Middle East Technical University.

Fernández, R. (2008). Culture and economics. In S. N. Durlauf and L. E. Blume (Eds.), The New Palgrave Dictionary of Economics. Basingstoke: Palgrave Macmillan.

Fernández, R. and A. Fogli (2005a). Culture: An empirical investigation of beliefs, work, and fertility. Technical report.

Fernández, R. and A. Fogli (2005b). Fertility: The role of culture and family experience. Technical report.

Fernández, R., A. Fogli, and C. Olivetti (2002). Marrying your mom: Preference transmission and women's labor and education choices. NBER Working Papers 9234, National Bureau of Economic Research, Inc.

Giuliano, P. (2006). Living arrangements in Western Europe: Does cultural origin matter? IZA Discussion Papers 2042, Institute for the Study of Labor (IZA).

Göksel, I. (2013). Female labor force participation in Turkey: The role of conservatism. Women's Studies International Forum 41, Part 1, 45 - 54.

Guiso, L., P. Sapienza, and L. Zingales (2003). People's opium? Religion and economic attitudes. Journal of Monetary Economics 50(1), 225-282.

Guiso, L., P. Sapienza, and L. Zingales (2006). Does culture affect economic outcomes? Journal of Economic Perspectives 20(2), 23-48. 
Gürsel, S., G. Uysal, and A. Acar (2011). Women face institutional and cultural barriers to participation in the labor market. Betam Research Briefs 115, Bahcesehir University Center for Economic and Social Research (Betam).

Heineck, G. (2004, July). Does religion influence the labor supply of married women in Germany? The Journal of Socio-Economics 33(3), 307-328.

Heper, M. (2002). Revised Barcelona Process in the light of Turkish experience. Unpublished manuscript, Bilkent University.

Ichino, A. and G. Maggi (1999). Work environment and individual background: Explaining regional shirking differentials in a large Italian firm. NBER Working Papers 7415, National Bureau of Economic Research, Inc.

Ilkkaracan, I. (2012). Why so few women in the labor market in Turkey? Feminist Economics 18(1), 1-37.

Kocaman, T. (2008). Türkiye'de iç göçler ve göç edenlerin nitelikleri. Report, Kalkınma Bakanlığı (Ministry of Development).

Levine, D. I. (1993). The effect of non-traditional attitudes on married women's labor supply. Journal of Economic Psychology 14(4), 665-679.

Osili, U. O. and A. Paulson (2004). Institutional quality and financial market development: Evidence from international migrants in the U.S. Working Paper Series WP-04-19, Federal Reserve Bank of Chicago.

Sarıbay, A. Y. (1985). Türkiye'de Modernleşme, Din ve Parti Politikası: MSP Örnek Olayı. İstanbul: Alan Yayıncilık.

Sarıbay, A. Y. (2004). Milli Nizam Partisi'nin kuruluşu ve programının içeriği. In Y. Aktay (Ed.), Modern Türkiye'de Siyasi Düşünce. İstanbul: İletişim Yayınları.

Tabellini, G. (2007). Institutions and culture. Working Papers 330, IGIER (Innocenzo Gasparini Institute for Economic Research), Bocconi University.

Tansel, A. (2001). Economic development and female labor force participation in Turkey: Time-series evidence and cross-province estimates. Working Papers 0124, Economic Research Forum.

Taymaz, E. (2009). Growth, employment, skills and female labor force. Working papers, Economic Research Center, Middle East Technical University.

Toprak, B. (1984). Politicization of Islam in a secular state: the National Salvation Party in Turkey. In S. A. Arjomand (Ed.), From Nationalism to Revolutionary Islam, pp. 119-133. New York: State University of New York Press.

Vella, F. (1994). Gender roles and human capital investment: The relationship between traditional attitudes and female labour market performance. Economica 61(242), 191-211. 


\section{A Appendix}

Figure 3: Share of women who perform namaz (a daily religious ritual)

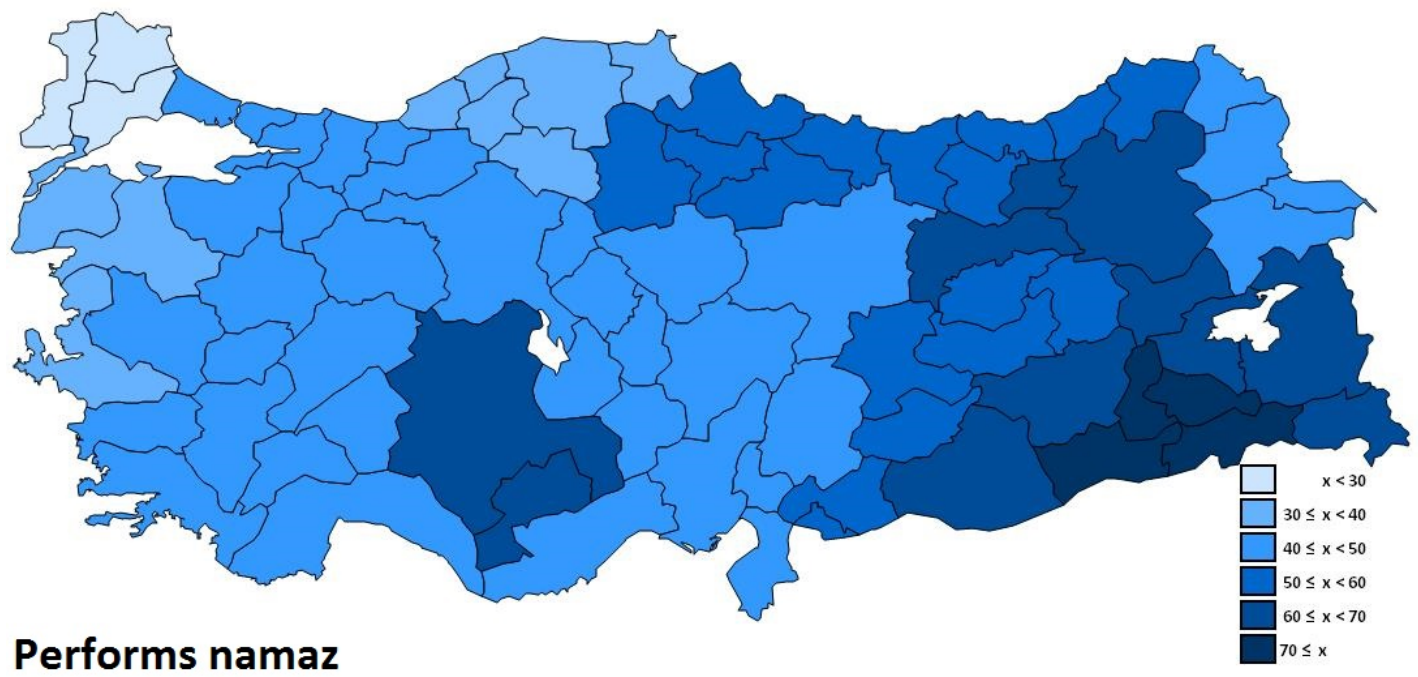

Figure 4: Share of women who received Baslik (Bride price)

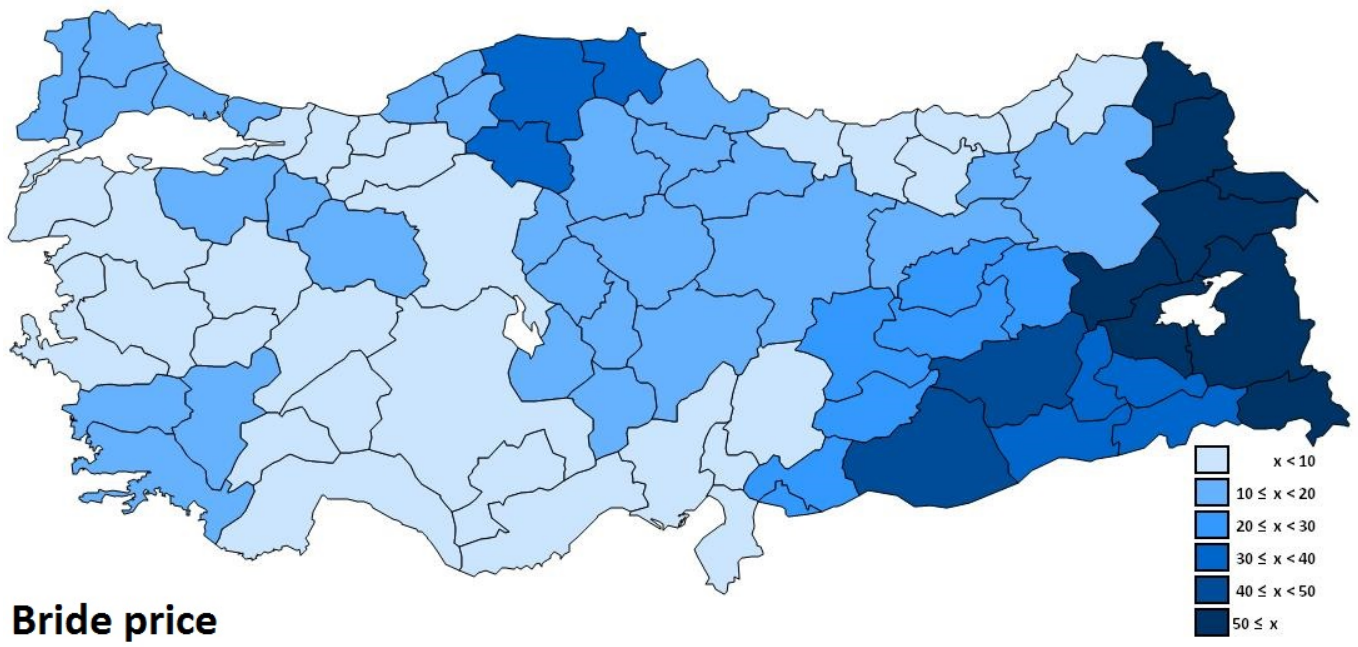


Figure 5: Share of women who were not asked consent for marriage

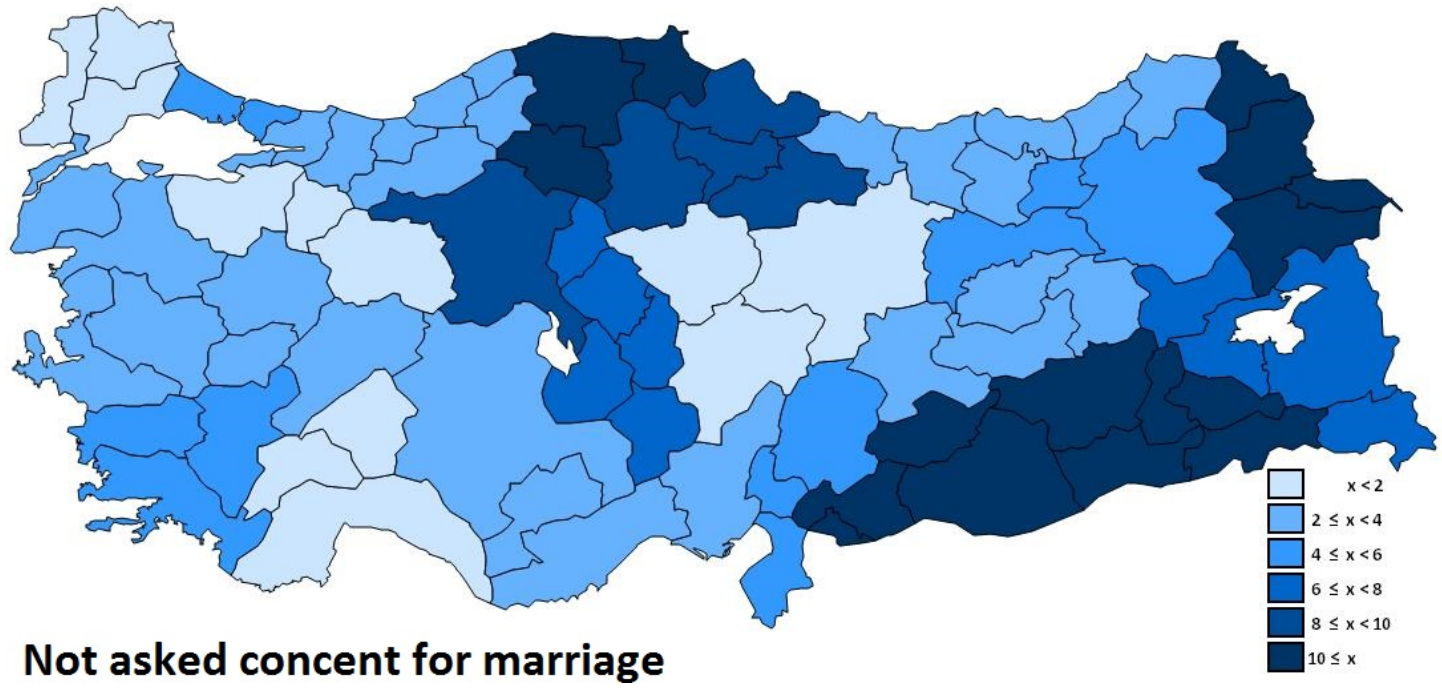

